\title{
ASSESSING THE MACROECONOMIC IMPACT OF BREXIT THROUGH TRADE AND MIGRATION CHANINELS
}

\section{9}

Antoine Berthou, Angel Estrada, Sophie Haincount, Alexander Kadow, Moritz A. Roth and narie Elisabeth de la senve.

Documentos Ocasionales N. 1911

\section{BANCODEESPAÑA}

Eurosistema 
ASSESSING THE MACROECONOMIC IMPACT OF BREXIT THROUGH TRADE

AND MIGRATION CHANNELS 


\section{ASSESSING THE MACROECONOMIC IMPACT OF BREXIT THROUGH TRADE AND MIGRATION CHANNELS ${ }^{(*)}$}

Antoine Berthou, Sophie Haincourt and Marie-Elisabeth de la Serve BANQUE DE FRANCE

Ángel Estrada and Moritz A. Roth (*)

BANCO DE ESPAÑA

Alexander Kadow

DEUTSCHE BUNDESBANK

${ }^{(*}$ ) The views expressed in this manuscript are those of the authors and do not necessarily represent the views of the Banco de España, Banque de France, Deutsche Bundesbank or the Eurosystem. All remaining errors are ours. $\left.{ }^{\star \star}\right)$ Corresponding author: moritz.roth@bde.es.

Documentos Ocasionales. N. 1911 
The Occasional Paper Series seeks to disseminate work conducted at the Banco de España, in the performance of its functions, that may be of general interest.

The opinions and analyses in the Occasional Paper Series are the responsibility of the authors and, therefore, do not necessarily coincide with those of the Banco de España or the Eurosystem.

The Banco de España disseminates its main reports and most of its publications via the Internet on its website at: http://www.bde.es.

Reproduction for educational and non-commercial purposes is permitted provided that the source is acknowledged.

C BANCO DE ESPAÑA, Madrid, 2019

ISSN: 1696-2230 (on-line edition) 


\section{Abstract}

This joint work by the Bundesbank, the Banque de France and the Banco de España highlights some of the numerous channels through which Brexit will affect the UK economy and its economic partners. In particular, it focuses on trade and migration channels, adding a more general assessment of exiting the EU through the use of a gravity model. The trade channel alone may cut UK GDP by $2 \%$ over the medium term if the UK reverts to WTO rules, while a more general gravity model would point to UK GDP falling by almost 6\% compared to baseline. According to our analysis, the 'cost of non-Europe' (such as originally stated by Cecchini's seminal work in 1988) lies therefore between $2 \%$ and $6 \%$ in terms of real GDP losses for the UK. With the shock being largely asymmetric, the EA remains relatively unscathed by the UK's exit, with GDP less than 1\% lower than baseline by 2023. The study also shows that results are sensitive to the envisaged policy response. In general, monetary and fiscal policies may act to cushion a Brexit-related shock; however, the potency of the policy response depends on the underlying source of the shock.

Keywords: Brexit, NiGEM, trade, tariffs, non-tariff trade barriers, migration, scenario analysis.

JEL classification: F15, F42, F53. 


\section{Resumen}

Este trabajo conjunto de Bundesbank, Banque de France y Banco de España analiza en detalle algunos de los numerosos canales a través de los cuales el brexit afectará a la economía del Reino Unido y a la de sus socios comerciales. En particular, se centra en los canales comercial y migratorio, haciendo una evaluación más general de los costes de la salida de la UE utilizando un modelo de gravedad. El canal comercial por sí solo puede reducir el PIB del Reino Unido un $2 \%$ a medio plazo si el Reino Unido vuelve a las reglas de la OMC, mientras que un modelo de gravedad más general apuntaría a que el PIB del Reino Unido se reduciría casi un $6 \%$ en comparación con el escenario de no salida. Por lo tanto, de acuerdo con nuestro análisis, el "coste de estar fuera de Europa» (como se estableció originalmente en el trabajo seminal de Cecchini en 1988) se encuentra entre el $2 \%$ y el $6 \%$ en términos de pérdidas del PIB real para el Reino Unido. Este impacto es en gran medida asimétrico, ya que el PIB de la zona del euro no se ve prácticamente afectado por este evento, al situarse menos de un $1 \%$ por debajo del escenario de no salida en 2023. El estudio también pone de manifiesto cómo los resultados son sensibles a la reacción de las políticas económicas. En general, las políticas monetarias y fiscales pueden actuar para amortiguar el shock del brexit; sin embargo, su efectividad depende de la fuente subyacente de la perturbación.

Palabras clave: brexit, NiGEM, comercio, aranceles, barreras no arancelarias, migración, análisis de escenarios.

Códigos JEL: F15, F42, F53. 
INDEX

Abstract 5

Resumen 6

1 Introduction 8

2 An overview of the economic impact of Brexit according to the literature 10

3 Trade scenario simulations 12

3.1 Impact of higher tariffs through import prices and export markets 13

3.2 The impact of non-tariff trade barriers (NTBs) 17

3.3 Global trade volumes 23

4 Migration scenario simulations 28

5 Conclusion 31

References 32

Appendix 1 Overview of GDP effects of Brexit in the literature

(from Bisciari, 2019) 33

Appendix 2 Methodological approach for import price and export market size shocks 34 


\section{Introduction}

The outcome of the June 2016 referendum on the United Kingdom's (UK) membership of the European Union (EU) was favourable to the UK exiting the EU and inaugurated a period of considerable uncertainty. In the days following the consultation, there were general declines in stock market indices and sterling depreciated by around 10\% against the dollar and the euro. The swift reaction of the Bank of England, which adopted several accommodative measures, helped ease tensions in financial markets.

The UK formally requested the exit from the EU in March 2017; several weeks later, it initiated a process of negotiations with the EU-27 on the withdrawal agreement, first, and on the future economic relationship, at a later date. As established by the Treaty on the Functioning of the EU. While the original March 2019 deadline for Brexit has been postponed, the current expectation is that the UK may no longer be part of the EU from the end of October 2019 onwards or even earlier if an agreement with the EU is reached before this deadline.

The UK is the second largest economy in the EU by GDP. It has very intense trade relations with the rest of the EU, and is its main trading partner. It also attracts many European workers and many British citizens live in other European countries. The British economy's specialisation in the financial sector, with London a global financial centre, makes it a key element in the functioning of the EU financial system. In short, the UK occupies a central place in EU commercial and financial relations and its potential departure may have repercussions on both sides of the English Channel.

As the negotiations to date have shown, disentangling and restructuring economic ties in Europe is a formidable task. There are several red lines on both sides. The nature of the future relationship that ultimately emerges from this process will inevitably determine the longterm economic implications of the UK's exit. In particular, the economic impact of a future relationship based on a free trade agreement (FTA) - with zero tariffs for goods and low, if any, non-tariff barriers (NTBs) - may turn out to be quite different from an outcome involving trade under World Trade Organization (WTO) rules.

While the effects of Brexit began to be felt after the referendum result ${ }^{1}$, the bulk of the macroeconomic impact should emerge following actual exit. This analysis aims to estimate the relative importance of some of the channels through which these effects are likely to materialise. One of them is the trade channel, since the increase in tariffs and NTBs - be it under an FTA or under WTO rules - will entail a change in the relative prices of imports and exports between the UK and the EU-27 and can have trade diversion effects among different areas. In order to assess the impact of new trade rules, we combine different analytical tools and models, simplifying to some extent the enormous complexity that the exit process represents, and highlighting the rather large range of potential economic effects.

1 For instance Crowley, Exton and Han (2018) find that in 2016 around 5\% fewer UK firms decided to export their goods and $4 \%$ more UK firms decided to cease exporting owing to Brexit uncertainty. 
A second important channel is migration, as imposing barriers on the entry of migrants into the UK is bound to alter the flows of migrants throughout the EU. Different analytical tools are also combined in this case to obtain quantitative estimates. We do not explicitly include financial spillovers, given the remarkable complexity involved in these types of linkages and the absence of sufficiently developed models to capture this channel. We also refrain from explicitly modelling channels other than trade and migration, such as potential changes to total factor productivity (TFP) caused by a reduction in the degree of the UK economy's openness after Brexit and restrictions on foreign direct investment flows between the EU and the UK. These channels are implicitly included in the trade volume scenario insofar as they impact trade flows between the UK and other countries.

This paper is the result of a joint effort by economists from the Bundesbank, the Banque de France and the Banco de España, using a common econometric tool, the NiGEM. The paper is organised as follows. We first review the existing literature assessing the potential economic impact of Brexit on the UK, the euro area (EA) and the world, with a particular focus on the British economy. In the second section, we provide results of the impacts that materialise through the trade channel, using different partial equilibrium methodologies and considering different possibilities as to how to introduce the trade shock into a general equilibrium model such as NiGEM, which is widely used to analyse spillovers between countries. The third section is devoted to reviewing the migration channel, also combining analytical partial equilibrium tools with NiGEM. The fourth section concludes. 


\section{An overview of the economic impact of Brexit according to the literature}

Since the referendum, many institutions and researchers have offered estimates of the potential impact of Brexit on both the British economy and the EU. As Bisciari (2019) shows, the estimated effects on economic activity reveal remarkable variability (see Appendix 1 for an overview). Most of the differences are explained both by the type of commercial and financial relationship that may be finally established between the UK and the EU and by the channels of transmission considered in the estimations.

The scenarios considered in the initial studies ranged from "benign" environments, preserving most of the existing commercial relationship between the UK and the EU, to other, more adverse scenarios, in which this relationship was governed by WTO rules. In these studies, released in 2016 and 2017, the estimated impact for the British economy was a reduction in the level of GDP of between $1.4 \%$ and $7.7 \%$ in the long term, depending on the scenario and hypotheses contemplated (see Figure 1). The estimates for the euro area and the world economy were noticeably more modest, though with significant differences across countries, depending on the specific links with the UK.

In parallel with these assessments, analysts revised their forecasts for the UK economy significantly downwards for the following years. In particular, the downward revisions for 2017 went from the European Commission's 0.9 percentage points (pp) to the Bank of England's $1.5 \mathrm{pp}$. Although the growth rates finally posted by the UK in 2017 and 2018 exceeded the post-referendum forecasts, they have remained significantly below the projections made before this event. In addition, it is important to note that in these two years advanced economies experienced significantly higher growth rates than anticipated in 2016. It is evident, therefore, that the British economy has lost pace relative to its peer group.

IMPACT ON GDP LEVELS (a)

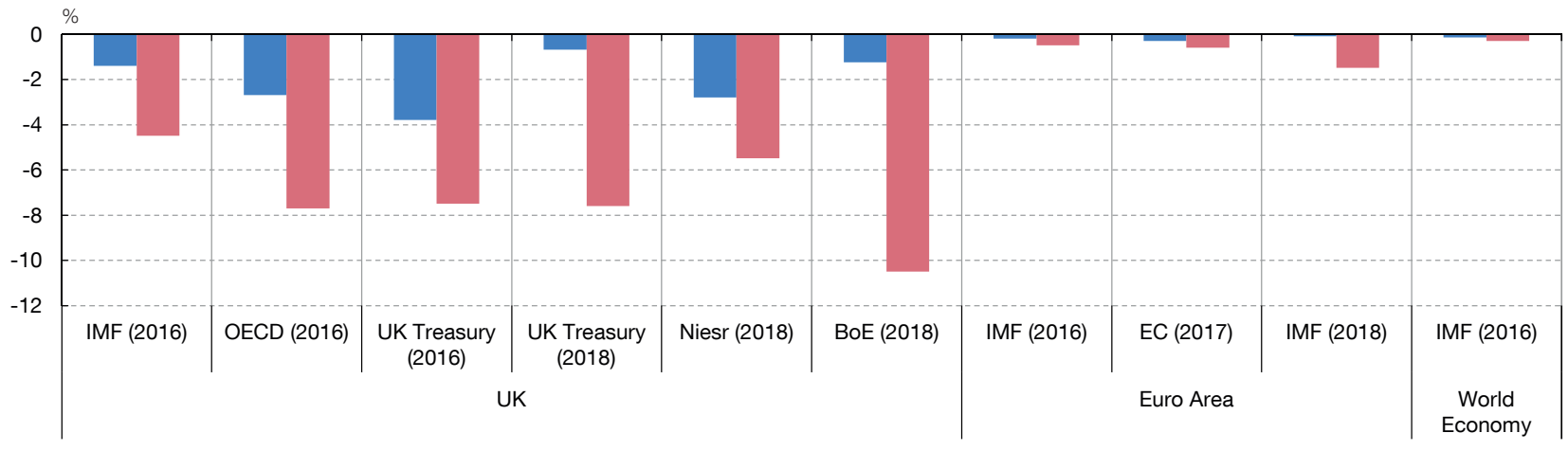

BENIGN SCENARIO ADVERSE SCENARIO

SOURCES: OECD, IMF, Bank of England, NIESR, European Comission and UK Treasury.

a Long-term impacts (horizon at least 2030), despite IMF 2016 (horizon 2021) and BoE (horizon 2023). 
The latest estimates of the impact of Brexit on the British economy have raised to some extent the expected long-term impact compared with the estimates made two years ago (Figure 1, studies referring to 2018). Both the Treasury and the Bank of England have conducted exercises in order to advise the Parliament. The Treasury (2018) considers that there are four possible scenarios for the commercial and financial relationship with the EU, although two of them would not meet the minimum requirements set by the British Government. In the first place, if the new relationship were similar to that in the White Paper prepared by the British Government, with no significant change in trade relations, the loss of GDP would be only $0.7 \%$; this would imply some recovery from the losses already experienced in 2017 and 2018. However, the loss would reach 2.2\% in the event of higher NTBs. An EEA-type agreement, with zero tariff rates and customs agreements would represent a loss of $1.4 \%$, which would rise to $4.9 \%$ in the event of a free trade agreement with zero tariffs and NTBs. The worst scenario for the UK would be under WTO rules, with a GDP loss of $7.6 \%$. A loss of almost 2 pp would have to be added to these negative impacts if the free movement of persons with the EU were to be eliminated.

The work by the Bank of England (2018) also points to different impacts depending on the agreement finally reached. Two scenarios are considered. The benign one involves maintaining the economic partnership, which consists of free trade in goods and partly in services; it then distinguishes between a situation in which customs controls and other barriers remain at a minimum level and another situation in which they increase. In the first case, the UK GDP would be 1.25\% lower than the Bank's May 2016 trend forecast by the end of 2023, entailing some recovery of part of the GDP loss already experienced in 2017 and 2018. Increasing the barriers to trade physically causes the loss of GDP to be $3.75 \%$ in comparison to the trend, which is higher than the loss experienced over the last two years. The pessimistic scenario is one in which no agreement is reached between the two blocs and trade relations are based on WTO tariffs. In this case, the worst scenario would be for the UK not to be able to sign new trade deals replacing those it now has access to because it is an EU member. Here the cost in terms of GDP would be $10.5 \%$ in comparison to the trend. If those trade agreements are replaced, the cost would be somewhat lower but still very significant $(-7.75 \%)$.

Finally, the National Institute of Economic and Social Research (NIESR), which provides one of the tools used in this paper to quantify the impact of Brexit, namely the National Institute Global Econometric Model (NiGEM), has also made its own assessment. Its estimates turn out to be lower than those presented above. According to these estimates, in the event of no agreement the UK would lose 5.5\% of GDP by 2030 in comparison to their baseline scenario, and if it were to enter into an FTA, the loss would fall to 3.9\%. A third scenario in which the UK maintains most of the agreements of the EU for a limited time would lead to a loss of $2.8 \%$ of GDP. 


\section{Trade scenario simulations}

The main focus of this paper is on the trade and migration channels through which Brexit might impact economic activity in the UK and elsewhere. Furthermore, we focus on the medium run, i.e. the next five years starting from 2019. We report the effects of Brexit on both the UK and the Euro Area (EA).

Using NiGEM ${ }^{2}$ we quantify the macroeconomic effects of these channels through scenario simulations. In what follows we explain in greater detail how the different simulation scenarios are set up. Common to all of our scenarios is the time horizon of the simulations and the effects we show. We compare our NiGEM scenario simulation results to the model baseline scenario. The reported simulation results are the impact of Brexit at a 5-year horizon starting in 2019 Q1. Therefore, the simulated impacts are shown as deviations from the NiGEM baseline scenario at the end of 2023.

In our central WTO scenario, monetary policy is switched off and agents make adaptive (backward) expectations. This means that we assume that agents do not anticipate the additional risk of a "hard Brexit" over a "soft Brexit". As a result, exchange rates do not react to the shocks and possible exchange rate adjustments are not considered in our study. In alternative scenarios, we allow monetary policy to respond to the shocks but the backward nature of agents' expectations prevents any significant reaction on the part of exchange rates (even under open arbitrage assumptions).

\section{Baseline scenario}

As outlined by NIESR (2018), ${ }^{3}$ the NiGEM 2018 Q3 baseline used in the simulations assumes a "soft Brexit" defined as:

"the UK and the EU maintain a very high level of access to each other's market for both goods and services, fully functioning financial markets, free movement of labour, a budgetary contribution that is broadly unchanged and a 21-month transition period after the UK exits the EU in March 2019 during which the country remains bound by regulations of the single market and customs union."

\section{Risk scenarios}

Our main risk scenario assesses the potential impact of a "hard Brexit" after a 21-month transition period. This means that we assume that the UK exits the EU in an orderly fashion with a Brexit deal in March 2019, but that within the 21-month transition period the UK and the EU do not find common ground for a trade agreement. As a consequence, the main risk scenario assumes that trade relations revert to WTO rules as of 2021 Q1 and remain under these rules.

2 National Institute Global Econometric Model v3.18-c, Brexit \& Tariff version is used throughout the paper.

3 National Institute Economic Review No. 245 August 2018, Box E, page F30. 
This scenario can be termed an "orderly hard Brexit" as it involves a transition period and does not take into account the uncertainty effects surrounding a scenario that would see the UK leaving the EU in a disorderly fashion without agreeing to a Brexit deal.

We simulate several variants of our main risk scenario by considering different specifications of the trade channel. In the first two scenarios we investigate the effects of different types of trade barriers that may appear after Brexit: one explores the macroeconomic consequences of direct tariffs on goods; the second assesses the impact of NTBs, such as bureaucratic obstacles to goods and services trade. Those scenarios focus on the impact through trade flows between the UK and the EA economies. A third scenario assesses the effect of Brexit on international trade flows, not only on British and European trade flows. Here the approach taken to measure the shock is a gravity estimation; in this way all possible channels through which the Brexit dis-integration process might affect trade flows are implicitly considered. Therefore, not only tariffs and NTBs are reflected in these estimates, but also a wider range of channels. Finally, we also consider the possibility of a Brexit without a transition period.

Below we outline the specific assumptions under which each scenario is conducted along with the simulated macroeconomic effects, starting with the tariff barrier scenario.

\subsection{Impact of higher tariffs through import prices and export markets}

In the event of a Brexit with no trade agreement between the UK and the EU, import duties applied by the UK to EU goods would be $4.2 \%$ on average per country while import duties applied by EU countries to the UK would average 5.3\%. ${ }^{4}$

Against this background, we implement two different shocks in NiGEM: a shock to the size of the export market of the UK and other EU countries; and a shock to the import prices of UK and EU countries. The methodological approach is explained in detail in Appendix 2. Tables 1 and 2 summarise the calibration of the size of the export market and the import price shocks.

The calibration of the foreign demand shock implemented in the export equation of NiGEM is reported in Table 1. We shock the demand variable 'S' (market size) for 7 countries: the UK, Germany, France, Italy, Spain, Belgium and Ireland. The shocks to variable 'S' are permanent and endogenous. The calibration of the shock to the non-commodity import price equation is reported in Table 2. We shock the variable 'PMNCOM', for the UK, Germany, France, Italy, Spain, Belgium and Ireland. The shocks to the variable 'PMNCOM' are permanent and exogenous. As can be seen, both shocks are highly asymmetric, as the EU accounts for a large share of British trade, whereas the UK represents a small share of each individual EU country's total trade.

4 See Cappariello (2017). 
Shock on export market size

\begin{tabular}{|c|c|c|c|c|c|c|}
\hline Country & $\begin{array}{l}\text { Nigem } \\
\text { variable }\end{array}$ & "Elasticity" & Tariffs & $\begin{array}{c}\text { Share of the UK in country's } \\
\text { export market share }\end{array}$ & $\begin{array}{c}\text { Share of the EU in the UK's } \\
\text { export market share }\end{array}$ & $\begin{array}{c}\text { Size of the shock } \\
(\%)\end{array}$ \\
\hline Belgium & BGS & 4 & 5.3 & $8.9 \%$ & - & $-2.0 \%$ \\
\hline France & FRS & 4 & 5.3 & $8.6 \%$ & - & $-2.0 \%$ \\
\hline Germany & GES & 4 & 5.3 & $7.6 \%$ & - & $-1.7 \%$ \\
\hline Ireland & IRS & 4 & 5.3 & $17.1 \%$ & - & $-3.9 \%$ \\
\hline Italy & ITS & 4 & 5.3 & $6.0 \%$ & - & $-1.4 \%$ \\
\hline Spain & SPS & 4 & 5.3 & $10.2 \%$ & - & $-2.3 \%$ \\
\hline United Kingdom & UKS & 4 & 4.2 & - & $44.6 \%$ & $-8.0 \%$ \\
\hline
\end{tabular}

SOURCE: IMF Direction of Trade Statistics (trade weights 2013-2016) - Authors' calculations.

CALIBRATION OF THE IMPORT PRICE SHOCK

Shock on import prices

\begin{tabular}{|c|c|c|c|c|c|c|c|}
\hline Country & $\begin{array}{l}\text { Nigem } \\
\text { variable }\end{array}$ & "Elasticity" & Tariffs & $\begin{array}{l}\text { Share of the UK in country's } \\
\text { total import prices }\end{array}$ & $\begin{array}{l}\text { Share of the EU in the } \\
\text { UK's total import prices }\end{array}$ & $\begin{array}{l}\text { Share of non commodity import } \\
\text { prices in total import prices }\end{array}$ & $\begin{array}{c}\text { Size of } \\
\text { the shock (\%) }\end{array}$ \\
\hline Belgium & BGPMNCOM & 4 & 4.2 & $4.7 \%$ & - & $79 \%$ & $1.0 \%$ \\
\hline France & FRPMNCOM & 4 & 4.2 & $6.2 \%$ & - & $86 \%$ & $1.2 \%$ \\
\hline Germany & GEPMNCOM & 4 & 4.2 & $4.9 \%$ & - & $87 \%$ & $0.9 \%$ \\
\hline Ireland & IRPMNCOM & 4 & 4.2 & $23.4 \%$ & - & $96 \%$ & $4.1 \%$ \\
\hline Italy & ITPMCOM & 4 & 4.2 & $4.8 \%$ & - & $81 \%$ & $1.0 \%$ \\
\hline Spain & SPPMNCOM & 4 & 4.2 & $5.6 \%$ & - & $80 \%$ & $1.2 \%$ \\
\hline United Kingdom & UKPMNCOM & 4 & 5.3 & - & $51.9 \%$ & $87 \%$ & $13.0 \%$ \\
\hline
\end{tabular}

SOURCE: IMF Direction of Trade Statistics (trade weights 2013-2016) - Authors' calculations.

We also test how the results might be affected by taking into account extra fiscal receipts from higher tariffs. Assuming that the government balance has to hit a target, we let the solvency rule adjust the actual government balance to its target through direct taxes on households. In this particular case, higher tariffs will mean higher fiscal receipts which, provided the government budget meets the target, will be redistributed to households through lower taxes.

Results of the import price and market size shocks are shown in Figure 2. Assuming no monetary policy accommodation, UK GDP following exit from the EU is $1.7 \%$ lower than the baseline by 2023. The shock is instantaneous in the case of inflation (up 0.9 pp in the first year) and private sector investment (both residential and corporate), down 2.6\% compared to baseline, rapidly followed by consumer spending as higher inflation hits household real income. Lower activity pushes down employment and employees' earnings, reinforcing the negative impact on income and consumption. The negative accelerator effect sets in, pushing down business investment further. Growth in the capital stock slows, hitting potential growth 


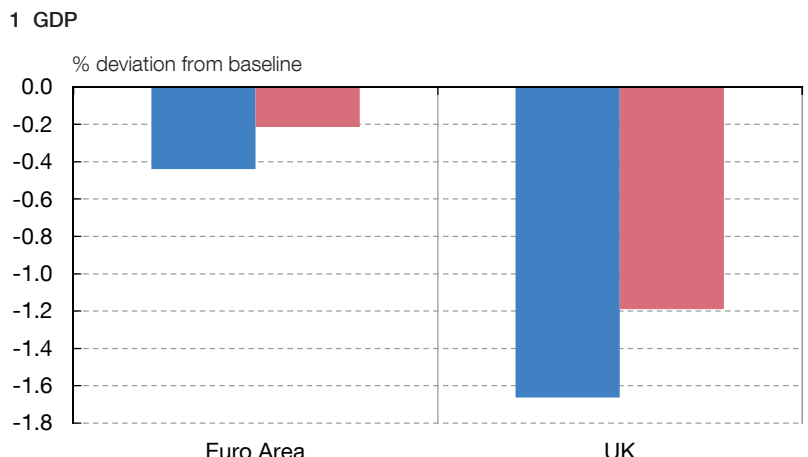

\section{TRADE BALANCE}

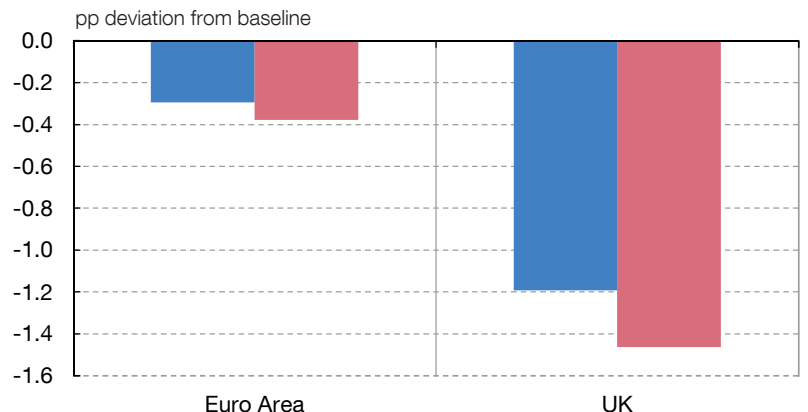

5 INFLATION

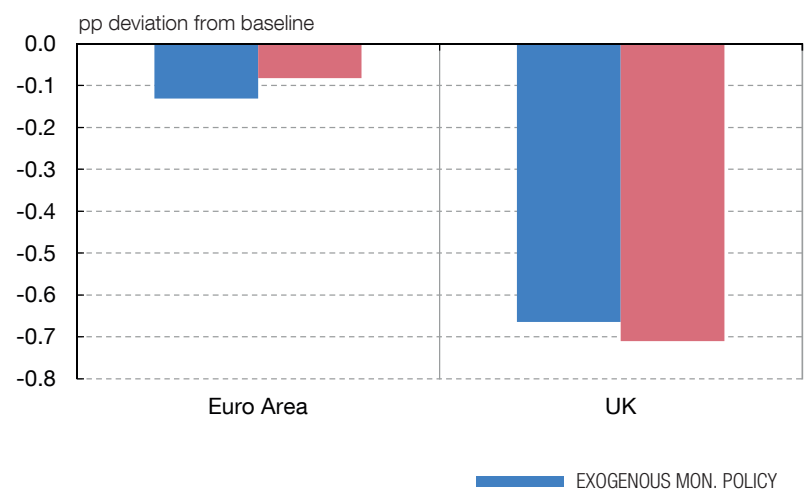

2 CONSUMPTION

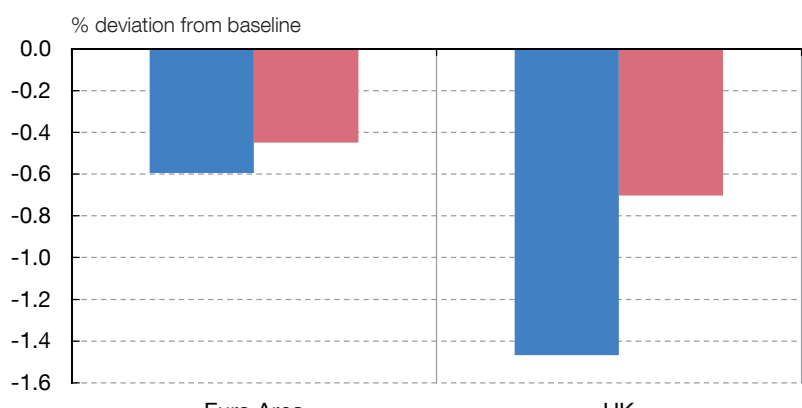

Euro Area

UK

\section{EMPLOYMENT}

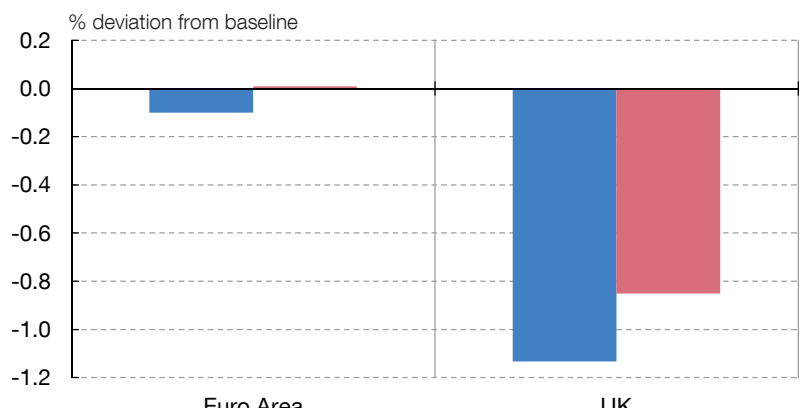

Euro Area

UK

\section{INTEREST RATE}

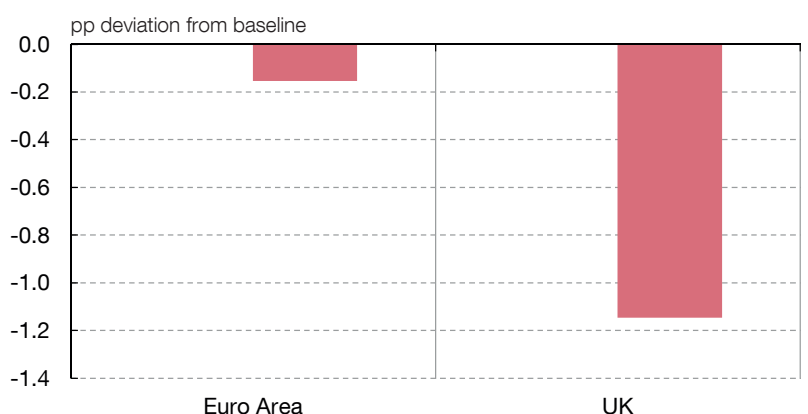

ENDOGENOUS MON. POLICY

SOURCE: NiGEM simulations.

and output, down $0.8 \%$ by 2023 . Trade volumes are 7\% lower by 2023 and the trade balance deteriorates by $1.2 \mathrm{pp}$, reaching a deficit of $4 \%$ of GDP in 2023 . With the budget solvency rule active, the government balance remains unchanged compared to baseline.

As shown in Figure 2, monetary policy can smooth the impact on the UK economy by cutting the policy rate. The cut amounts to around 100bp by 2023 (monetary policy follows a two-pillar rule). As a result, the negative shock to private investment and consumer spending is halved. UK GDP is ultimately $1.2 \%$ below the baseline, compared to $1.7 \%$ in the case of no monetary policy reaction. 
According to the simulations, the EA remains relatively unscathed by the UK exit, with GDP $0.4 \%$ lower than baseline by 2023 . However, lower trade $(-1.8 \%$ on average for export and import volumes) hampers employment and employees' earnings. As a result, consumer spending in the EA is proportionally more impacted than private sector investment.

A decomposition of each shock highlights the dominance of the export market shock, i.e. the importance of the response of export volumes to changes in prices and tariffs (see Appendix 2 for the theoretical approach). As shown in Figure 3, the negative impact of Brexit on UK GDP stems solely from the export market shock, while the import price shock actually contributes positively to the overall impact on UK GDP. In a scenario where only import prices are impacted by higher tariffs, import volumes fall compared to baseline (-2.6\% after 5 years) as import prices rise, while UK exports are only marginally impacted. As a result, net trade makes a positive contribution to GDP, more than offsetting the negative impact on consumer spending and private investment.

This mechanism relies heavily on the assumption that agents (households and corporations alike) can replace imported goods with domestic goods. This is a limitation of NiGEM in assessing the effects of import tariffs in our Brexit scenario. When tariffs increase, the foreign goods can be replaced by a locally produced substitute. This reduces the consequences for households and companies of the protectionist measures resulting in price increases. A second limitation is that the import equation does not distinguish between households' and firms' demand. In reality, part of the production in the UK is highly integrated into global value chains. This production requires highly specific products manufactured in mainland Europe, which are then assembled with other British inputs and then re-exported to the EU or the rest of the world (think of the assembly of Aerospace engines by the British company Rolls-Royce, which requires a huge amount of parts and components from mainland Europe and is used in aircraft assembly in the rest of the world). Higher input tariffs would lead to increasing production costs for British firms, and this negative productivity shock

\section{DECOMPOSITION OF THE TWO TRADE SHOCKS FOR THE UK}

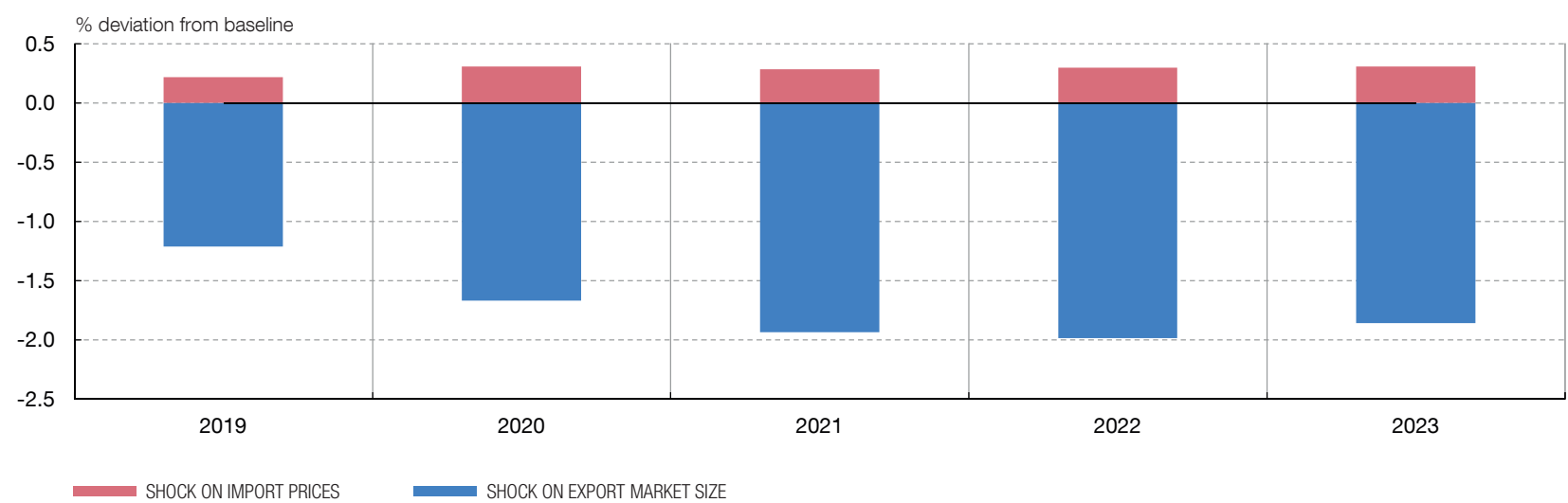

SOURCE: NiGEM simulations.

NOTE: agents are backward-looking and monetary policy does not react. 
1 UK GDP

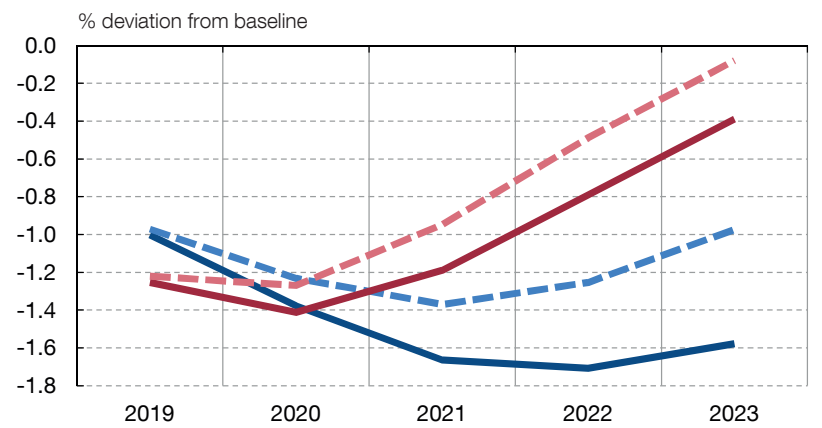

MONETARY POLICY INACTIVE; NO EXTRA FISCAL RECEIPTS MONETARY POLICY ACTIVE; NO EXTRA FISCAL RECEIPTS
2 EA GDP

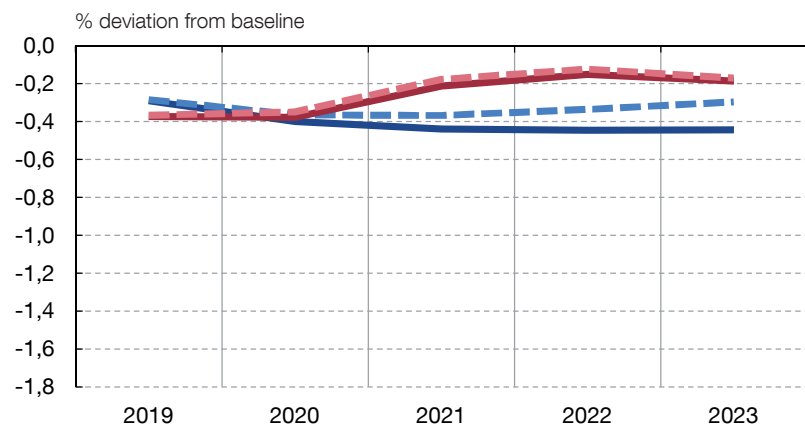

- - " MONETARY POLICY INACTIVE; EXTRA FISCAL RECEIPTS - - - " MONETARY POLICY ACTIVE; EXTRA FISCAL RECEIPTS

SOURCE: NiGEM simulations.

is not controlled for in our simulation given the structure of the NiGEM model. For these reasons, the simulation probably underestimates the consequences of Brexit on UK's GDP through the import channel.

When adding to the central WTO scenario the amount of fiscal receipts stemming from higher tariffs, either with or without monetary policy reaction, the outcomes are those shown in Figure 4.

Fiscal receipts stemming from higher tariffs are calculated outside of the model, multiplying the ex-post value of UK total imports by the import tariff (5.3\% in this case), adjusted by the share of the EU in UK total imports. The same approach is applied to the main EU countries. According to this metric, tariff-induced fiscal receipts would amount to $0.9 \%$ of ex-ante GDP for the UK and Ireland, and less than $0.2 \%$ for other EA countries, in the absence of a monetary policy reaction (the figures are marginally higher when monetary policies are active). As the solvency rule is activated $^{5}$, all of the extra fiscal receipts are redistributed to households through lower income taxes, in a permanent way. As a result, the negative shock to UK GDP is reduced by $0.3 \mathrm{pp}$ at the 3-year horizon, at $-1.4 \%$ compared to $-1.7 \%$ in the case of no fiscal boost. This implies a fiscal multiplier of around 0.3 , a figure in line with the literature.

\subsection{The impact of non-tariff trade barriers (NTBs)}

While trade barriers from Brexit may arise at the border in the form of tariffs or customs checks, the potential emergence of additional NTBs is of particular importance in the policy debate. Let us turn, then, to the role of NTBs. NTBs typically refer to behind-the-border-policy measures

5 In NiGEM, a tax rule ensures that governments remain solvent in the long run by bringing the deficit or debt stock back to sustainable levels after any shock. The fiscal solvency rule means that the actual net public sector borrowing adjusts to the target NPSB through the direct tax rate on households. 
and can take various forms, including conformity assessments, licensing or other national requirements that need to be met. NTBs thus affect the price of goods and services traded, the quantity traded, or both. NTBs are not economically harmful per se; for instance, they may reduce information asymmetries or ensure that particular (e.g. sanitary) standards are met, thereby enhancing consumers' trust in imported products. However, there is compelling evidence that NTBs remain significant obstacles to trade and nowadays they often matter more than tariff barriers (Berden and Francois, 2015). This is why modern trade agreements seek to strengthen the degree of regulatory cooperation between trading partners.

From a methodological point of view, there is no obvious way to quantify the extent of NTBs. ${ }^{6}$ Quantity-based approaches use gravity equations to estimate by how much NTBs affect trade flows, whereas price-based approaches seek to back out differences in import prices (due to a specific NTB) and world prices (in the absence of the NTB). NTBs are typically quantified as tariff equivalents (ad-valorem equivalents), providing a headline number on the degree of regulatory divergence between economies in particular sectors or at an aggregate level. ${ }^{7}$ This also allows for a direct comparison with tariff rates and hence seems a natural way to incorporate shock sizes in a consistent manner into macroeconometric models.

While it is not obvious how to quantify NTBs in the case of Brexit, the unique institutional arrangements of the EU Single Market, reflecting a deep trade arrangement, suggest that any remaining NTBs should be small. Brexit implies an unwinding of previous trade integration steps. However, how quickly and to what extent this process may evolve remains unknown at this stage. Modellers are therefore required to adopt a stance on different possible exit scenarios.

One approach is to rely on estimates for NTBs in tariff equivalent terms for countries outside the EU (say the United States or Norway) and use informed judgement to scale estimates. The figures provided by Dhingra et al. (2017) are derived along those lines and have received some attention in the literature (Vandenbussche et al., 2017, for example, apply the same shock sizes). ${ }^{8}$ Dhingra et al. (2017) report an overall weighted average of NTBs for flows of goods and services from the United States to the EU of $20.4 \%$, of which more than half can potentially be reduced. The authors claim that, after Brexit, the UK could face one-quarter of those reducible costs or, in a pessimistic scenario, three-quarters of the reducible costs.

In the remainder of this section we resort to the particular work of Felbermayr et al. (2017). Their study contains trade cost estimates on a sectoral level in line with the classification

6 See Berden and Francois (2015) for a further discussion.

7 Ad-valorem equivalents thus seek to reflect the tariff rate that would have an effect as equally restrictive as the corresponding NTB.

8 More specifically, Dhingra et al. (2017) decompose trade costs into a time-varying reducible component and a fixed unreducible component. The reducible part of overall trade costs is claimed to decay over time where the remaining share of the reducible component is set exogenously and determines the nature of pessimism in the underlying scenario. 
from the World Income Output Database (WIOD). ${ }^{9}$ Unlike other studies on Brexit, the authors emphasise the view of regulatory convergence. That is to say, their estimates do not seek to capture levels of trade costs due to different regulatory standards; rather, they measure to what extent trade costs have been reduced by trade integration shocks (the EU Eastern enlargement, for example). Using estimates from gravity equations, industry-specific trade elasticities are used to back out effects with respect to trade costs on a sectoral level. Their estimates thus reflect historic reductions in trade costs for the UK and the EU-27 from European integration which, in the case of a WTO Brexit scenario (i.e. in the absence of a comprehensive free trade agreement or other arrangements), could re-emerge.

Table 3 summarises the estimated change in (bilateral) trade costs for the EU-27, the EA-19 and the UK. A distinction is made with regard to cost contributions arising specifically from goods and services trade, respectively. The figures imply that UK exporters would be more affected by dis-integration than vice versa. Overall effects for other European countries are close to the EA average, as suggested by the similar estimate obtained for the EU-27. Looking at the relative importance of goods and services sectors, it appears that UK service providers may find it increasingly difficult to conduct business in the euro area. This is in contrast to relatively competitive and less regulated services sectors in the UK at this stage. The estimates reported here are in line with those used in studies of comparable scope. ${ }^{10}$

The chosen quantification of trade costs is not free from caveats. First, based on gravity equations, the underlying estimates essentially assume that cost reductions implied by previous trade integration steps would be fully reversed if the UK were to leave the Single Market. This arguably marks an upper bound. Also, the degree and speed at which trade costs increase is unclear at this stage. On the other hand, it seems a natural starting point to consider effects of disintegration as a form of unwinding of previous trade integration steps. ${ }^{11}$ Moreover, the estimates suggest that there are asymmetric effects with regard to NTB reductions. Taken at face value, British exporters would be more affected by Brexit (where the degree varies on a sectoral level) than EU-27 exporters trading with the UK. This is based on aggregate empirical evidence reported by Felbermayr et al. (2017).

CHANGE IN TRADE COSTS UNDER A WTO SCENARIO

\begin{tabular}{lccc} 
& & & \multicolumn{2}{c}{ Contributions } \\
\cline { 3 - 4 } Country & Overall & Goods & Services \\
\hline EU-27 & 12.1 & 8.3 & 3.8 \\
\hline EA-19 & 12.1 & 8.4 & 3.7 \\
\hline UK & 18.7 & 10.2 & 8.6
\end{tabular}

SOURCE: Authors' calculations based on Felbermayer et al. (2017)

NOTES: Bilateral NTBs as ad-valorem equivalents (in \%). Estimates reflect the perspective of an exporter facing changes in trade costs vis-à-vis the UK, the EU-27 or the euro area.

9 The 2016 release covering a period from 2000 to 2014 is used. See Timmer et al. (2015) for details.

10 See also Bisciari (2019) for a further discussion.

11 Felbermayr et al. (2018) use a similar approach to conduct a counterfactual analysis of various disintegration scenarios and highlight more generally the considerable welfare effects from membership of the EU Single Market. 
Next, we seek to shed light on the potential macroeconomic implications of trade costs arising from NTBs. As our particular interest is in highlighting different transmission channels (of which monetary policy responses are an important element), we confine our analysis to the EA vis-à-vis the UK. We focus on a medium-term horizon, looking through potential short-term volatility brought about by, for example, anticipatory household behaviour. We assume the presence of a transition period until the end of 2020. Results are, however, not materially affected by what in our case essentially boils down to a mere timing convention.

The expanded version of the NiGEM we use incorporates a split of volumes between UK exports to the other EU-27 countries and the rest of the world (ROW) and correspondingly for the other EU-27 countries' exports to the UK and the ROW, based on 2016 trade patterns. This allows us to directly shock bilateral export prices to capture the emergence of NTBs in EU trading relationships.

Our simulations assume permanent increases in trade costs. This assumption allows us to illustrate potential macroeconomic consequences arising from a "hard" Brexit. Because our adaptive expectations assumption rules out anticipatory effects, we abstract from additional exchange rate volatility. Under the current baseline, there is a mild nominal depreciation of sterling in effective terms. However, this response is likely to be more pronounced in the event of a hard Brexit and may act towards absorbing initial effects.

Without adopting a stance as to how regulatory regimes in Europe may evolve, we first consider a range of different scenarios with regard to changes in NTBs: a symmetric 10\% increase in NTBs for all euro area countries and the UK, a scenario in which the UK exporters permanently face higher NTBs compared to the euro area (quantifications are based on Table 3) and scenarios in which services sectors diverge over time, entailing additional NTB effects for the UK economy. We allow for endogenous responses of monetary policy throughout. Shocks to bilateral trade costs are introduced in the same manner as in the first set of simulations (i.e. through shocking export prices) to allow for consistent comparisons.

Figure 5 summarises the results for UK and euro area GDPs. As expected, the UK economy is relatively more affected than the euro area across all scenarios. This also applies to the "least severe" case of a symmetric increase in NTBs. Here, however, the difference in medium-term GDP losses is relatively small: UK GDP falls by the end of 2023 by $0.4 \%$ compared to baseline, while real GDP in the euro area declines by $0.3 \%$. Taken at face value, this would imply that frictions at the UK border could have direct and sizable implications for the euro area. In our benchmark scenario of a relatively stronger trade cost increase for UK exporters, the GDP loss for the euro area amounts to $0.5 \%$, compared to $0.8 \%$ for the British economy. Rising interest rates in response to inflationary effects due to higher trade costs depress domestic demand additionally, which in turn affects other economies' exports. Without the accompanying appreciation of the domestic currency, the UK monetary policy reaction causes a stronger negative effect on domestic demand for imported goods, amplifying the negative effect on other economies' exports. 


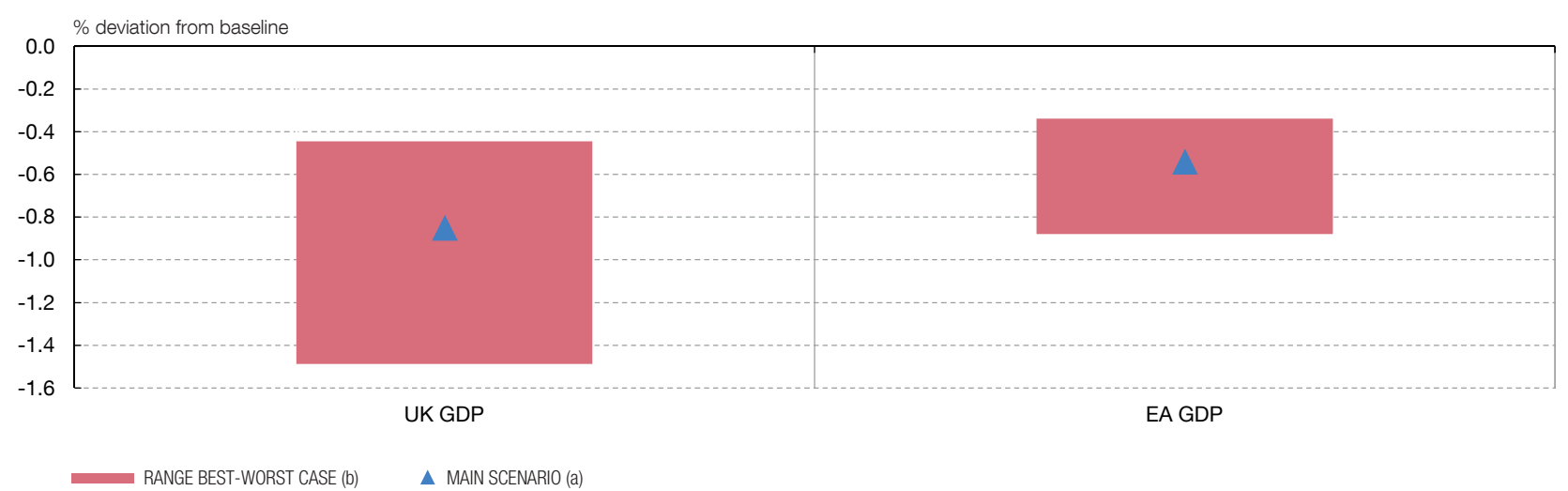

SOURCE: NiGEM Simulations.

a Main scenario: Asymmetric increase of NTBs.

b Range from scenarios of symmetric and asymmetric increases of NTBs as well as of UK regulatory divergence in service sectors.

To further investigate the role of monetary policy in the context of the model, we compare the effects resulting from endogenous interest rate responses to a set-up in which short-term interest rates are fixed ("exogenous monetary policy"). It should be noted, of course, that those are mechanical reactions of interest rates in line with standard monetary policy rules.

A summary of effects for selected variables is given in Figure 6. A key finding is that medium-term GDP effects tend to be more pronounced under endogenous monetary policy responses. This is because, on impact, the increase in trade costs acts in an inflationary manner in both countries (and considerably more in the case of the UK) which causes monetary authorities to tighten. This in turn depresses aggregate demand. Net trade improves mechanically in the face of a sharper fall in import than export volumes. There is only little room for trade diversion in the model: UK exports to the rest of the world hardly increase by 2023, whereas shipments to the rest of the EU drop by about $9 \%$. Over time, monetary policy turns more accommodative in response to the increasing negative output gap. In the medium term - Figure 6 depicts point estimates after five years of shock implementation - short-term interest rates in the UK are 0.5 pp below baseline, whereas in the Euro Area they hardly deviate from baseline. Assuming central banks look through the initial inflationary impact (i.e. abstracting from interest rate reactions), GDP effects prove to be less pronounced. As a result, negative effects on other countries' exports occurring through depressed domestic demand are smaller. However, even the milder GDP loss would translate into a noticeable hit to consumption and employment for the UK economy over the medium term.

Summarising, starting from a regime of regulatory equivalence between the EU-27 and the UK, a natural question to ask is to what extent regulatory frameworks may diverge over time, which translates into rising NTBs in the bilateral exchange of goods and services. How fast 
1 GDP

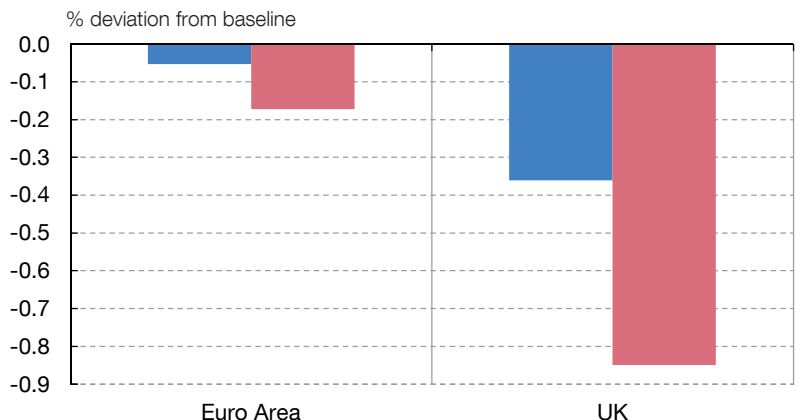

\section{CURRENT ACCOUNT}

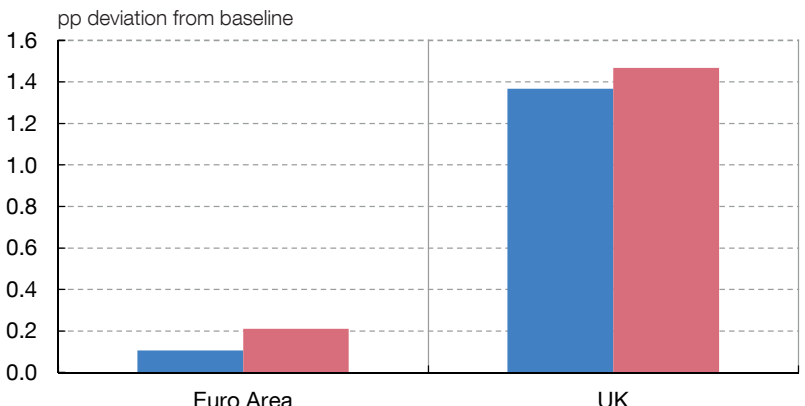

5 INFLATION

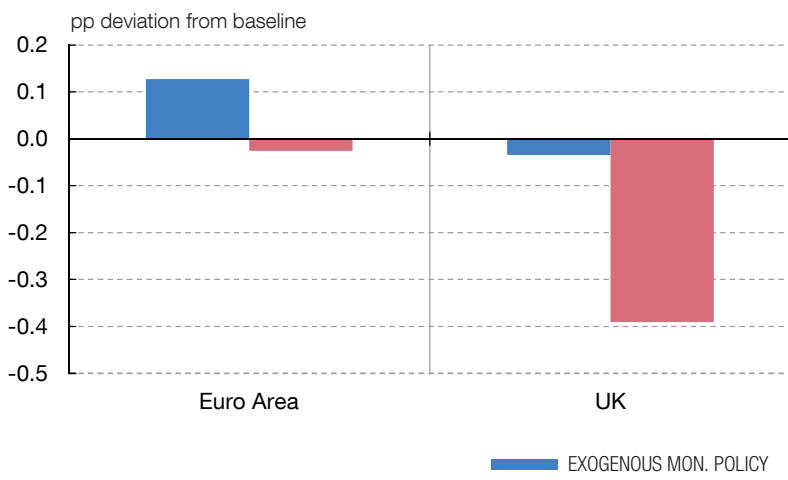

2 CONSUMPTION

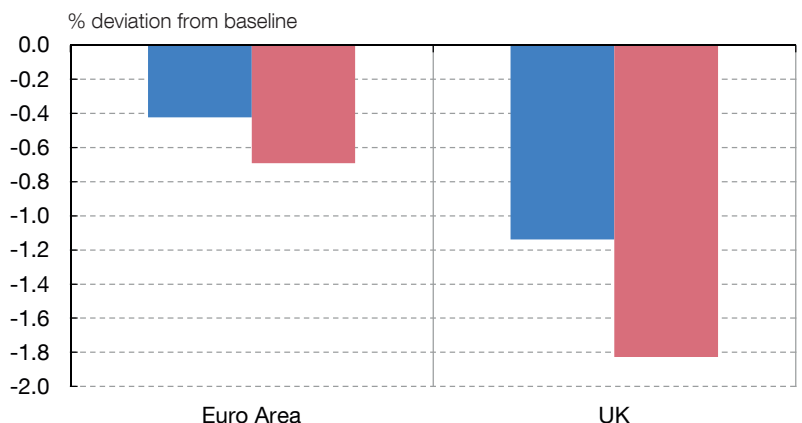

4 EMPLOYMENT

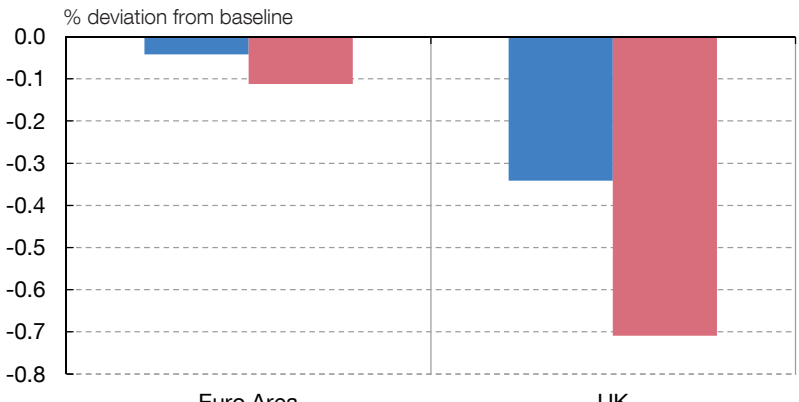

Euro Area

UK

\section{INTEREST RATE}

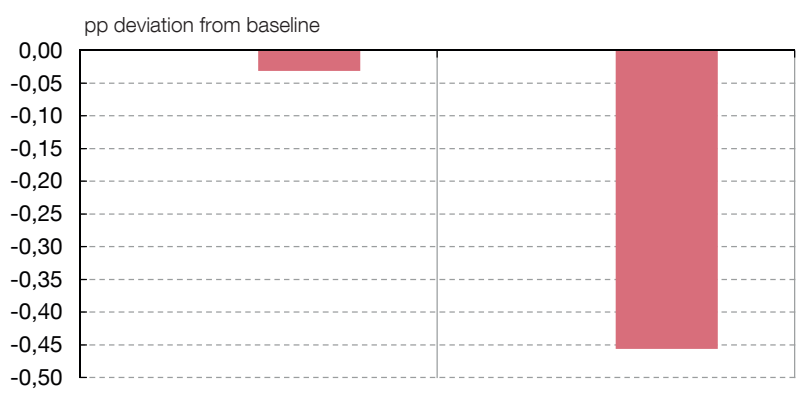

Euro Area

UK

SOURCE: NiGEM simulations.

and to what extent this happens remains an open question at this stage. Moreover, regulatory divergence may not be symmetric, suggesting that levels of NTBs could differ across countries and sectors. The simulation results presented should therefore not be interpreted as "point estimates" in any way. They are rather intended to highlight the potential role for NTBs in driving Brexit-related macroeconomic consequences.

Our results suggest that the UK economy in particular would be affected by the emergence of NTBs over the medium term. Overall effects appear relatively small, when considered in isolation, with medium-term GDP losses ranging from $0.4 \%$ to $0.8 \%$. However, we abstract from additional effects (for instance depressed productivity growth) which could be associated with looser trading relationships and act as a further drag on potential GDP 
growth. Also, it should be noted that in keeping with the quantified shock sizes which are expressed in tariff equivalent terms, we think of an increase in NTBs as a pure cost shock without immediate implications for the volume of goods and services traded. Yet while probably small over the medium term, the model essentially does not capture trade flows being diverted to other regions which would act towards mitigating negative impacts. Lastly and significantly, the simulated effects are sensitive to the assumed response of monetary policy. Given that Brexit-related increases in trade costs may be thought of as a negative supply shock, the scope for monetary policy to dampen effects with respect to NTBs may therefore be limited after all.

\subsection{Global trade volumes}

The third channel of impact of Brexit on trade that we analyse focuses on world trade volumes. Initially, we estimate the effect of European trade integration on international trade flows and specifically on trade between the UK and the EU. Because the estimation is based on total trade volumes, it covers the effects of both lower tariffs and NTBs, along with other channels affecting trade flows. First, the impact of Brexit on trade volumes is estimated by reversing the effects estimated for the European trade integration process. In a second step we estimate the international macroeconomic effects of these changes in trade flows by simulating different scenarios with the NiGEM model.

To obtain estimates of the impact on trade volumes between the UK and the EU we use the results obtained by Campos and Timini (2018), who estimate a structural gravity equation model of European integration. ${ }^{12}$

The dependent variable of this gravity equation model is export flows. In addition to the standard combination of fixed effects (country-pair, exporter-time and importer-time), the model includes a dummy variable for EU membership. ${ }^{13}$ To construct the WTO scenario the EU membership dummy variable is set to zero between country pairs that include the UK and other EU countries and then the model is solved for bilateral trade flows. ${ }^{14}$ Therefore, to measure the effects of European disintegration following Brexit on trade volumes between the UK and other European countries, we use the reverse of the estimate of the impact of EU membership on the UK. The estimates are based on data on bilateral trade flows (international and intra-national) from UN COMTRADE for the 1986-2006 period which is released every four years (following UNCTAD-WTO, 2016). The sample includes 69 origin and destination countries.

The estimated effects on bilateral trade flows are shown in Figure 7. These estimates indicate that in a post - Brexit steady - state of the world economy, the total trade volume of the UK would be depressed by around 30\% compared to a non-Brexit baseline scenario.

12 A detailed description of the methodology can be found in Campos and Timini (2018).

13 Furthermore, other dummies are included to account for Euro currency and free-trade area (FTA) effects.

14 By interpreting the estimates obtained in terms of the UNCTAD-WTO (2016) structural model, they obtain Conditional General Equilibrium (CGE) bilateral trade flows for different scenarios. The estimation is performed using Poisson Pseudo-Maximum Likelihood (PPML). 


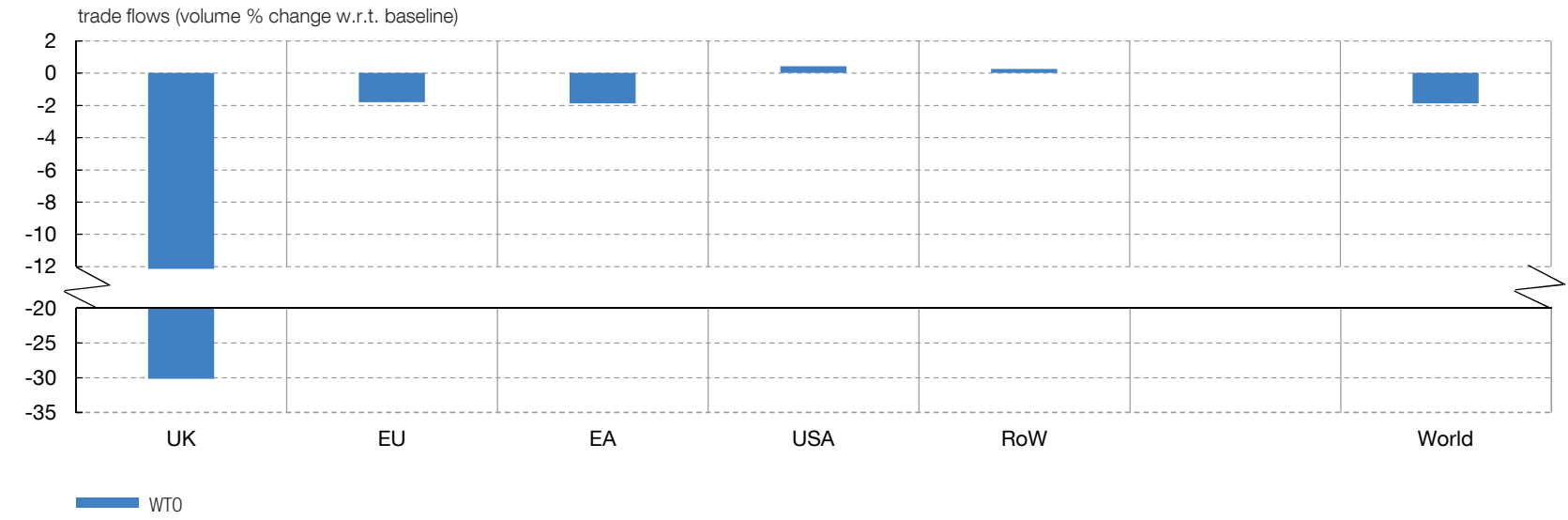

SOURCE: Campos and Timini (2018).

NOTE: When aggregated at the supranational level, results are the weighted average of trade flows.

The EU-27 and the Euro Area would also be negatively affected, albeit at a much lower level at around $-2 \%$. World trade would be reduced by a similar magnitude under this scenario, while the US and China would gain slightly in terms of total trade volume due to trade diversion effects. However, our main focus is the simulation of the impact of Brexit on the UK and the Euro Area.

By feeding the above trade effects into the NiGEM model we can simulate the macroeconomic effects that Brexit could have under a WTO scenario via bilateral trade flows. We compare our simulation of a "hard Brexit" to the NiGEM's baseline scenario which assumes a "soft Brexit".

Since the structural gravity model yields static steady-state effects, while the NiGEM model incorporates a time dimension under which these effects materialise, we assume that there is a transition from a pre-Brexit steady-state to a post-Brexit steady state, lasting around 5 years, after which the trade volumes stay at the lower post-Brexit level. The simulation results in Figure 8 show that the estimated effects of Brexit on trade volumes would lead UK GDP to deviate by $3.2 \%$ downwards from its baseline by the end of 2023 if the central bank were allowed to counteract the demand shock through a standard interest rate setting rule that weighs inflation and the country's output gap; the output loss would be $6 \%$ if the central bank did not react to this shock. In the first case, the central bank would lower the policy interest rate by $2.5 \mathrm{pp}$ more than under the baseline scenario. For the Euro Area the impact on activity would be less pronounced: GDP would fall by $0.1 \%$ under endogenous monetary policy and by $0.2 \%$ under fixed exogenous monetary policy. In the first case the ECB would lower interest rates by $0.1 \mathrm{pp}$ more than under the baseline scenario.

Inflation would fall by $1.4 \%$ below the baseline scenario for the UK under exogenous monetary policy, while the central bank's interest rate reduction would slightly mitigate this effect to $-1.1 \mathrm{pp}$. In the Euro Area, prices under both policy scenarios would fall slightly by $0.1 \mathrm{pp}$ with respect to the baseline. 
1 GDP

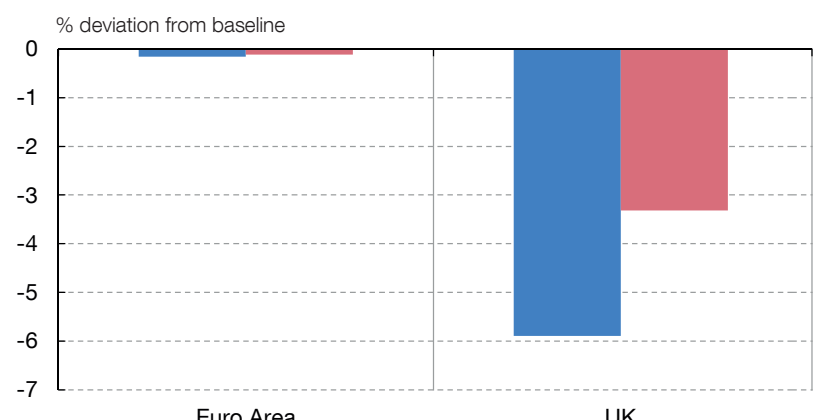

Euro Area

UK

3 CURRENT ACCOUNT

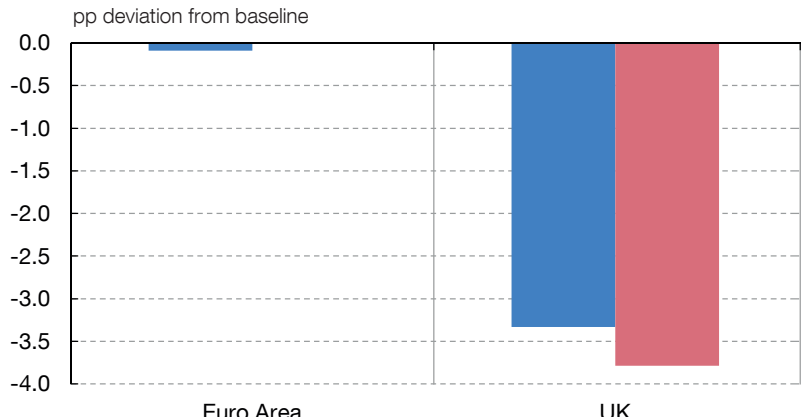

Euro Area

UK

\section{INFLATION}

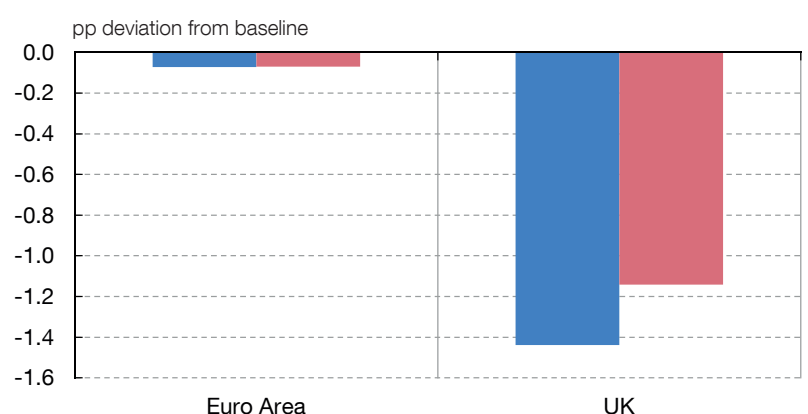

Euro Area

UK

EXOGENOUS MON. POLICY
2 CONSUMPTION

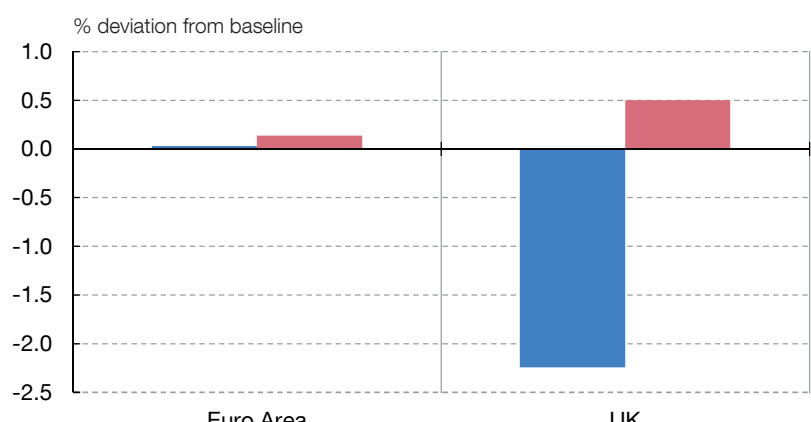

Euro Area

UK

\section{EMPLOYMENT}

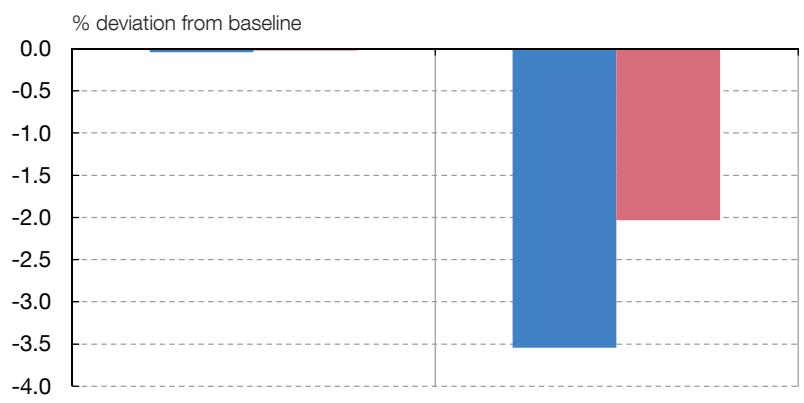

Euro Area

UK

\section{INTEREST RATE}

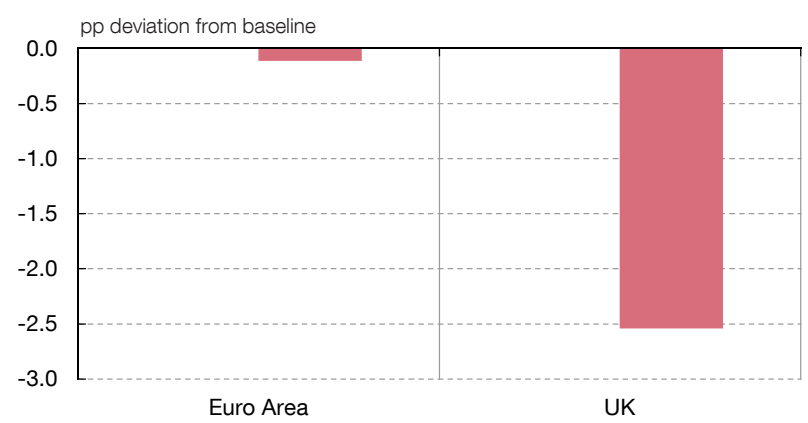

ENDOGENOUS MON. POLICY

SOURCE: NiGEM simulations.

\section{Alternative Scenarios}

To assess the degree of uncertainty around the main scenario, which assumes a 21-month transition period and a no-deal Brexit thereafter, we further investigate the impact through world trade flows - our third trade channel - by simulating two alternative robustness scenarios. The first alternative scenario, a milder one, assumes that a free trade agreement would follow a 21 -month transition period until 2021. The second scenario, a riskier one, assumes that a no-deal Brexit will be invoked at the end of March 2019 without a transition period 


\section{ENDOGENEOUS MONETARY POLICY}

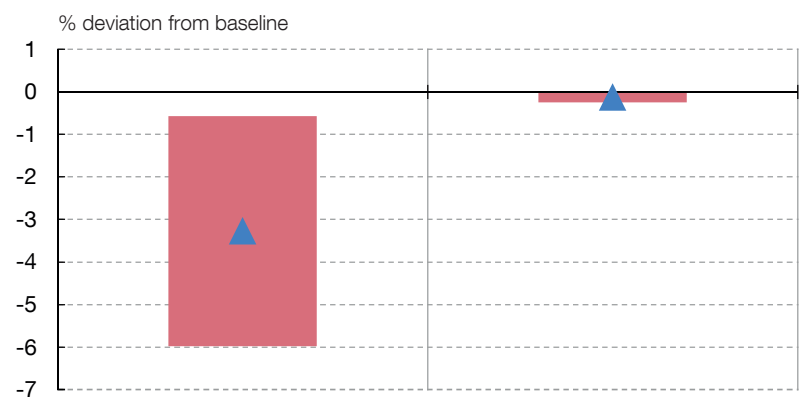

UKY
ELY

\section{EXOGENEOUS MONETARY POLICY}

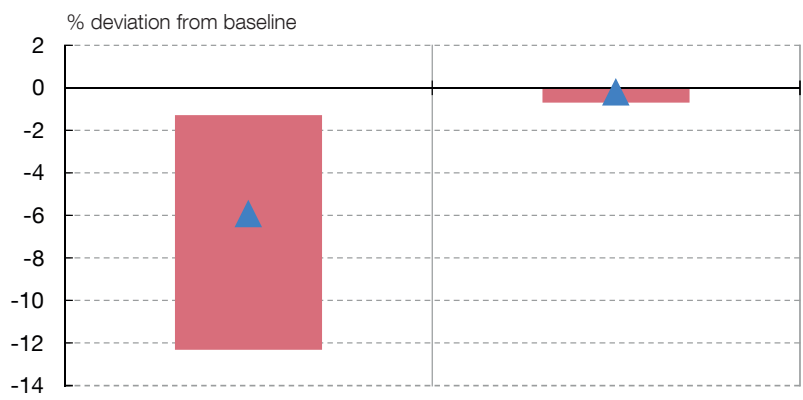

UKY

ELY

RANGE BEST-WORST CASE (b) $\quad \Delta$ MAIN SCENARIO (a)

SOURCE: NiGEM Simulations

a Main scenario: Asymmetric increase of NTBs.

b Range from scenarios of symmetric and asymmetric increases of NTBs as well as of UK regulatory divergence in service sectors.

and that trade relationships will revert to WTO rules from 2019 Q2 onwards ("No-Deal" Brexit). Furthermore, for each of these alternative scenarios we change the length of the period the world economy needs to adjust to the new post-Brexit steady state: to 3, 5 and 10 years. In total, this amounts to 9 alternative scenarios.

The red bars in Figure 9 show the range between the minimum and the maximum GDP impact for the UK and the Euro Area across all robustness scenarios at the end of 2023 as a percentage deviation from the NiGEM baseline. The blue dots represent the effect of estimates of the main scenario corresponding to the effects discussed in the previous section. The upper part of Figure 9 shows the impacts under the assumption that monetary policy reacts endogenously. For these scenarios the best case outcome ${ }^{15}$ for the UK would see GDP reduced by $0.6 \%$ compared to its baseline, while the worst case outcome ${ }^{16}$ would project GDP to fall by $5.4 \%$ owing to the reversal of trade effects as a result of European integration. For the Euro Area, GDP would increase slightly by $0.1 \%$ in the best case and decrease by $0.25 \%$ in the worst case scenario.

Owing to the fall in exports, the current account balance would decrease by 3.3 and 3.8 pp under exogenous and endogenous monetary policy, respectively, for the UK. For the Euro Area the current account would decrease by 0.1 and $0.0 \mathrm{pp}$, respectively. At the same time, employment would fall by $3.5 \%$ and $2 \%$, respectively, in the UK, while Euro Area employment would not be affected.

15 Best case: achieved with the assumptions of an FTA agreement after a 21-month transition period and assuming a 10-year steady-state transition.

16 Worst case: achieved under the assumption of a No-Deal Brexit without transition and under the assumption of a 3-year steady-state transition. 
The second graph yields the results if monetary policy remains unchanged at the baseline interest rate path. Because the trade volume shocks are deflationary and the central bank lowers rates if it is allowed to, GDP effects are mitigated through the monetary policy reaction. Under an exogenous monetary policy, GDP effects are therefore larger. For the UK, GDP is projected to fall by $1.3 \%$ in the best case scenario and $11 \%$ in the worst case scenario, with our main scenario falling close to the middle of this range ${ }^{17}$. Therefore, there is a substantial variation of potential outcomes depending on the circumstances under which the UK leaves the EU and how quickly the world economy adjusts to these new circumstances.

It should be noted that confidence effects around which outcome will ultimately be negotiated are not taken into account for these simulations. As NIESR (Nov 2018) points out, this means that the above simulations represent an orderly No-Deal scenario. If the UK were to leave the EU without a deal and this were not anticipated somehow by households and other economic agents, confidence effects and market disruptions might arise that would affect our results presumably more to the downside.

17 The respective best and worst case scenarios correspond to those with endogenous monetary policy. 


\section{Migration scenario simulations}

Brexit will not only impact the UK and EA economies through trade; migration flows are also bound to be a very important channel. To investigate this impact, we take the effects of Brexit on migration flows estimated by Campos and Timini (2018) to simulate their macroeconomic impact with NiGEM. The dependent variable in their gravity model measures bilateral migration flows and includes a dummy variable for free labour mobility within the EU. ${ }^{18}$ In the WTO scenario they set the free labour mobility and the customs union dummy variables to zero between country pairs that include the UK and other EU countries and then solve for bilateral migration flows. In addition, they assume that $7.5 \%$ of the current stock of EU immigrants returns from the UK to their countries of origin.

The bars in Figure 10 show the results of Campos and Timini (2018) through the migration channels under the WTO scenario. ${ }^{19}$ As in the trade volume scenario, we use these estimated impacts of Brexit on bilateral migration flows for the WTO scenario in the NiGEM to assess the macroeconomic impact of this scenario on a global level. We include the estimated effects over the 2018-2022 time horizon. We do this by adjusting the country-specific labour force variables in the NiGEM global economic model and simulate the world economy under these conditions over a 5-year horizon.

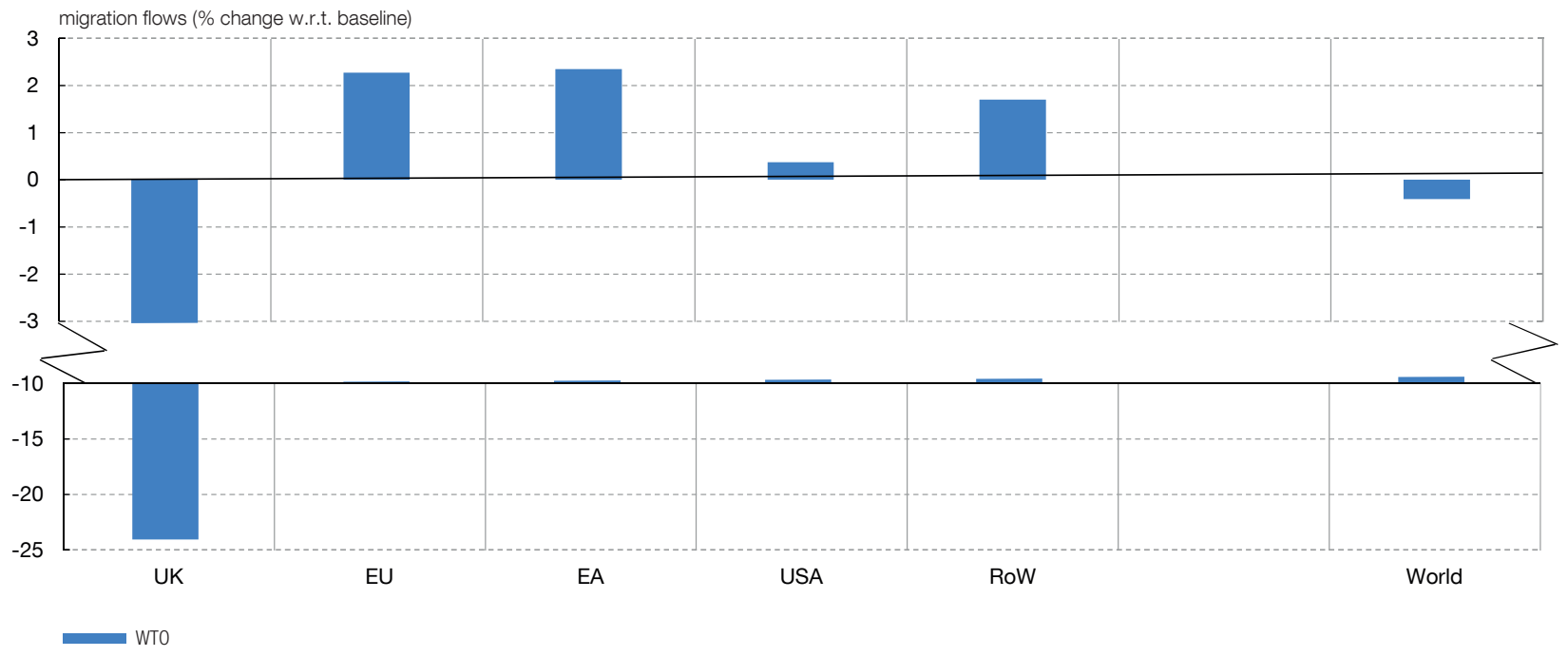

SOURCE: Campos and Timini (2018).

NOTE: When aggregated at the supranational level, results are weighted averages of population flows.

18 In addition to the standard gravity terms (distance, language, etc.), and similar to the trade volume scenario, dummies for a customs union and different types of free trade agreements are included. By interpreting their estimates in terms of Anderson's (2011) structural model they obtain Conditional General Equilibrium (CGE) bilateral migration flows in the full mobility scenario and in the alternative scenarios. The estimation is performed using Poisson Pseudo-Maximum Likelihood (PPML).

19 The data considered for this estimation include bilateral migration flows from the International Migration Database (IMD, OECD). Therefore, data are gross inflows to selected OECD destinations over the 1997-2015 period at a yearly frequency. In total, there are 206 origin and 35 destination countries. 
The simulation results are shown in Figure 11. They show that owing to the effects of Brexit on migration flows estimated using our gravity equation estimation approach, the UK's GDP is projected to deviate by $-0.4 \%$ from its baseline by the end of 2023 if the central bank is allowed to react to the negative supply shock to the labour force by raising interest rates, and by $-0.2 \%$ if the central bank does not react to this shock. In the first case, the central bank would raise the policy interest rate by $0.4 \mathrm{pp}$ more than under the baseline scenario. For the Euro Area the consequences are reversed. GDP would rise by $0.3 \%$ and $0.1 \%$ under reacting endogenous monetary policy and exogenous monetary policy, respectively, due to a higher migrant inflow and a larger labour force. In the first case, the ECB would lower interest rates by $0.2 \mathrm{pp}$ more than under the baseline scenario.

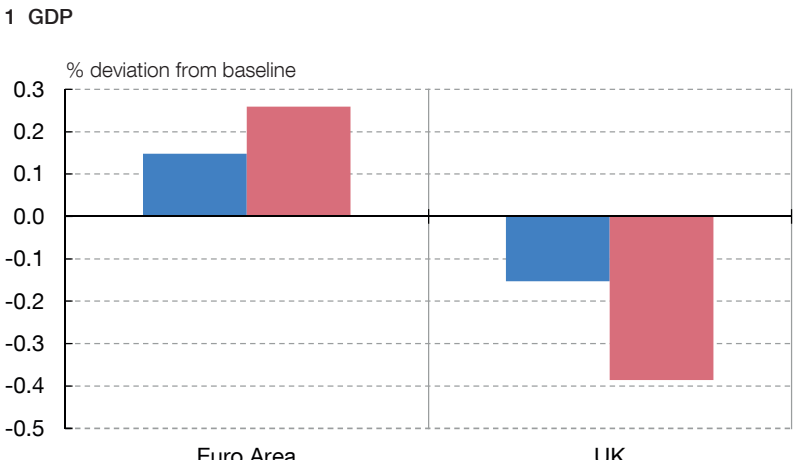

3 CURRENT ACCOUNT

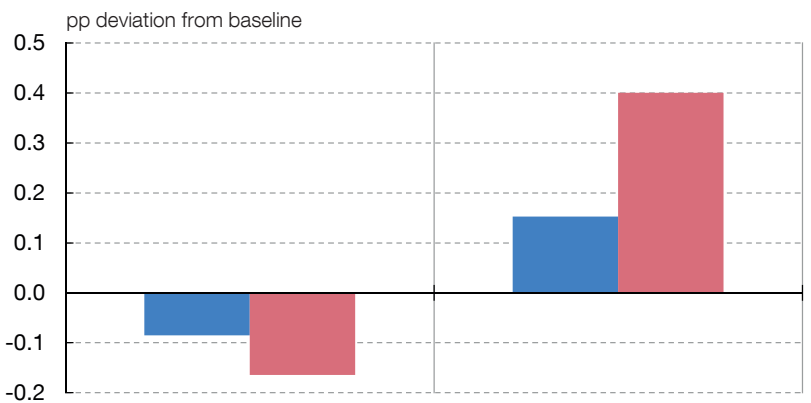

Euro Area

\section{CONSUMPTION}

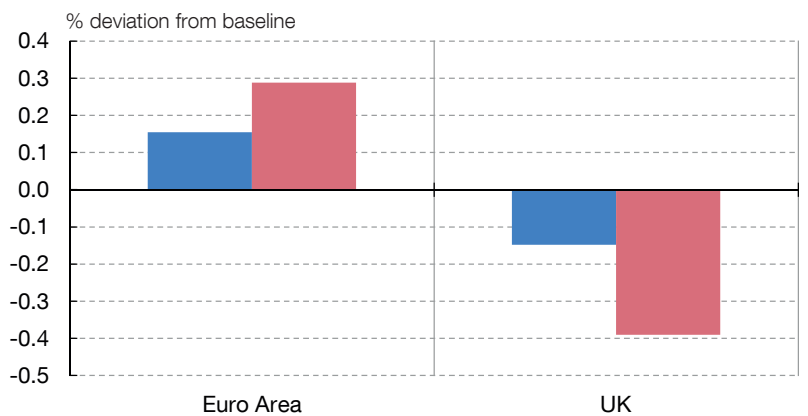

4 EMPLOYMENT

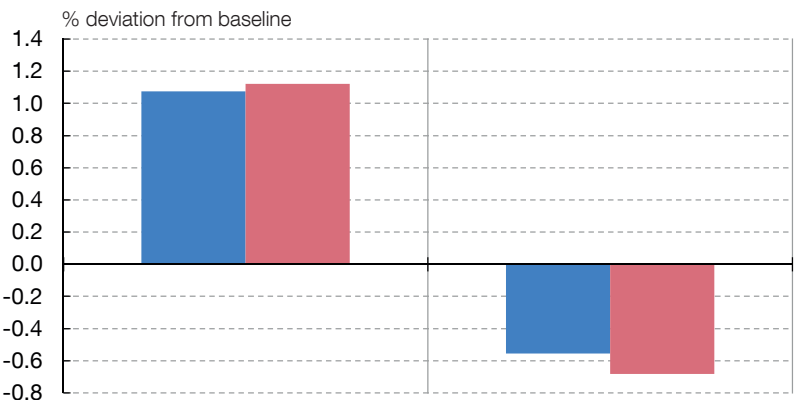

Euro Area

\section{INFLATION}

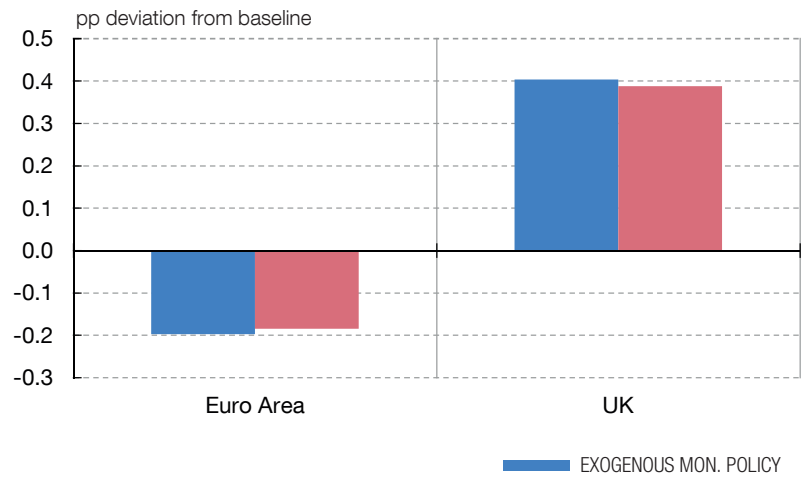

\section{INTEREST RATE}

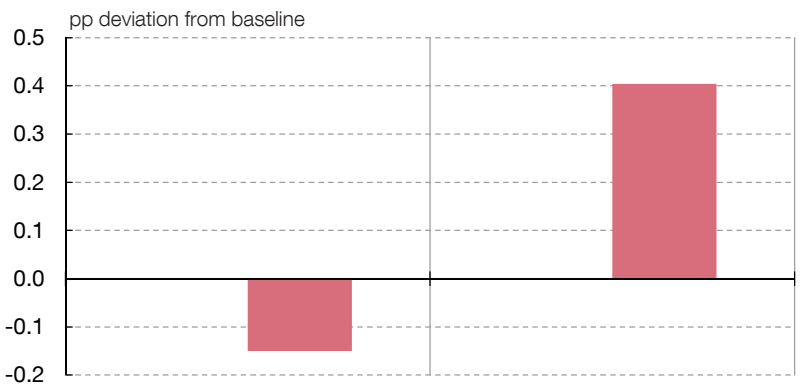

Euro Area

UK

SOURCE: NiGEM simulations. 
The current account balance would increase by 0.15 and 0.4 pp under exogenous and endogenous monetary policy, respectively, for the UK; in the case of the Euro Area it would decrease by around 0.1 and $0.2 \mathrm{pp}$. At the same time, employment would fall by 0.6 and $0.7 \%$, respectively, in the UK, while Euro Area employment would rise by $1.1 \%$ irrespective of the monetary policy reaction. Finally, inflation would rise by 0.4 pp above the baseline scenario for the UK under exogenous as well as endogenous monetary policy, while in the Euro Area the higher inflow of workers would lead to prices falling by 0.2 pp with respect to its baseline under both policy scenarios. 


\section{Conclusion}

This joint work by the Bundesbank, the Banque de France and the Banco de España highlights some of the numerous channels through which Brexit will affect the UK economy and its economic partners. In particular, it focuses on trade and migration channels, adding a more general assessment of exiting the EU through the use of a gravity model. The trade channel alone may cut UK GDP by $2 \%$ over the medium term if the UK reverts to WTO rules, while a more general gravity model would point to UK GDP falling by almost $6 \%$ compared to baseline. According to our analysis, the 'cost of non-Europe' (such as originally stated by Cecchini's seminal work in 1988) lies therefore between $2 \%$ and $6 \%$ in terms of real GDP losses for the UK. With the shock being largely asymmetric, the EA remains relatively unscathed by the UK's exit, with GDP less than 1\% lower than baseline by 2023. The study also shows that results are sensitive to the envisaged policy response. In general, monetary and fiscal policies may act to cushion a Brexit-related shock; however, the potency of the policy response depends on the underlying source of the shock.

Caveats to the results have been mentioned throughout in the corresponding sections of the paper. To reiterate, a medium-scale macroeconomic model, NiGEM, abstracts from various aspects of international trade which may impact on the estimated effects stemming from the trade channel. In particular, the lack of intermediate goods and the absence of knock-on effects of higher import costs on the value chain detracts from our results. 


\section{References}

BANK OF ENGLAND (2018). EU withdrawal scenarios and monetary and financial stability: A response to the House of Commons Treasury Committee.

BERDEN, K., and J. FRANCOIS (2015). Quantifying non-tariff measures for TTIP. Paper No. 12 in the CEPS-CTR project and CEPS Special Report No. 116.

BISCIARI, P. (2019). A survey of the long-term impact of Brexit on the UK and the EU27 economies, National Bank of Belgium, Working Paper 366.

CALIENDO, L., and F. PARRO (2015). "Estimates of the Trade and Welfare Effects of NAFTA," Review of Economic Studies, vol. 82(1), pages 1-44

CAMPOS, R., and J. TIMINI (2019). "An estimation of the effects of Brexit on trade and migration" Banco de España, Occasional Paper Series.

CAPPARIELLO, R. (2017). "Brexit: estimating tariff costs for EU countries in a new trade regime with the UK" Banca d'Italia Occasional Paper Series.

CROWLEY, M., O. EXTON and L. HAN (2018). "Renegotiation of Trade Agreements and Firm Exporting Decisions: Evidence from the Impact of Brexit on UK Exports", Mimeo

DHINGRA, S., H. HUANG, G. OTTAVIANO, J. P. PESSOA, T. SAMPSON and J. VAN REENEN (2017). The costs and benefits of leaving the EU: trade effects, Economic Policy 32: 651-705.

EUROPEAN COMMISSION (2017). "An Assessment of the Economic Impact of Brexit on the EU-27", Study for the IMCO Committee.

FELBERMAYR, G., J. GRÖSCHL and I. HEILAND (2018). Undoing Europe in a new quantitative trade model. ifo Working Papers No. 250.

FELBERMAYR, G., J. GRÖSCHL, I. HEILAND, M. BRAML and M. STEINIGER (2017). Ökonomische Effekte eines Brexit auf die deutsche und europäische Wirtschaft. Ifo Studie im Auftrag des Bundesministeriums für Wirtschaft und Energie (BMWi).

FONTAGNÉ, L., C. MITARITONNA and J. E. SIGNORET (2016). Estimated Tariff Equivalents of Services NTMs. CEPII Working Paper No. 2016-20.

HM GOVERNMENT (2016). "HM Treasury analysis: the long-term economic impact of EU membership and the alternatives". IMF (2016). "Macroeconomic implications of the United Kingdom leaving the European Union”, Selected issues, Art. IV, June.

IMF (2018). "The long-term impact of Brexit on the European Union", https://blogs.imf.org/2018/08/10/the-long-termimpact-of-brexit-on-the-european-union/, August.

KIERZENKOWSKI, R., N. PAIN, E. RUSTICELLI and S. ZWART (2016). The economic consequences of Brexit: a taxing decision. OECD Economic Policy Paper No. 16.

NIESR (2018). National Institute Economic Review No. 245

NORDAS, H. K., and D. ROUZET (2015). The impact of services trade restrictiveness on trade flows. OECD Trade Policy Papers No. 178

OECD (2016). The Economic Consequences of Brexit: A Taxing Decision. OECD Economic Policy Paper No. 16, April.

OECD (2018). Estimating ad-valorem equivalent of non-tariff measures: combining price-based and quantity-based approaches. Working Paper presented at Working Party of the Trade Committee Meeting in Paris, TAD/TC/ WP(2017)12/Rev1.

SAMPSON, T. (2017). Brexit: The economics of international disintegration, Journal of Economic Perspectives 31(4): 163-184.

THE HOUSE OF COMMONS TREASURY COMMITTEE (2018). The UK's economic relationship with the European Union: The Government's and Bank of England's Withdrawal Agreement analyses. Twenty-Fifth Report of Session 2017-19.

TIMMER, M. P., E. DIETZENBACHER, B. LOS, R. STEHRER and G. J. DE VRIES (2015). An illustrated user guide to the World Input-Output Database: the case of global automotive production, Review of International Economics 23(3): 575-605

VANDENBUSSCHE, H., W. CONNELL and W. SIMONS (2017). Global value chains, trade shocks and jobs: an application to Brexit. KU Leuven Center for Economic Studies Discussion Paper Series DPS17.13. 
LONG-TERM IMPACT ON GDP OF BREXIT IN A WTO SCENARIO

TABLE A.1.1 (pp of GDP/welfare deviation from EU-like scenario)

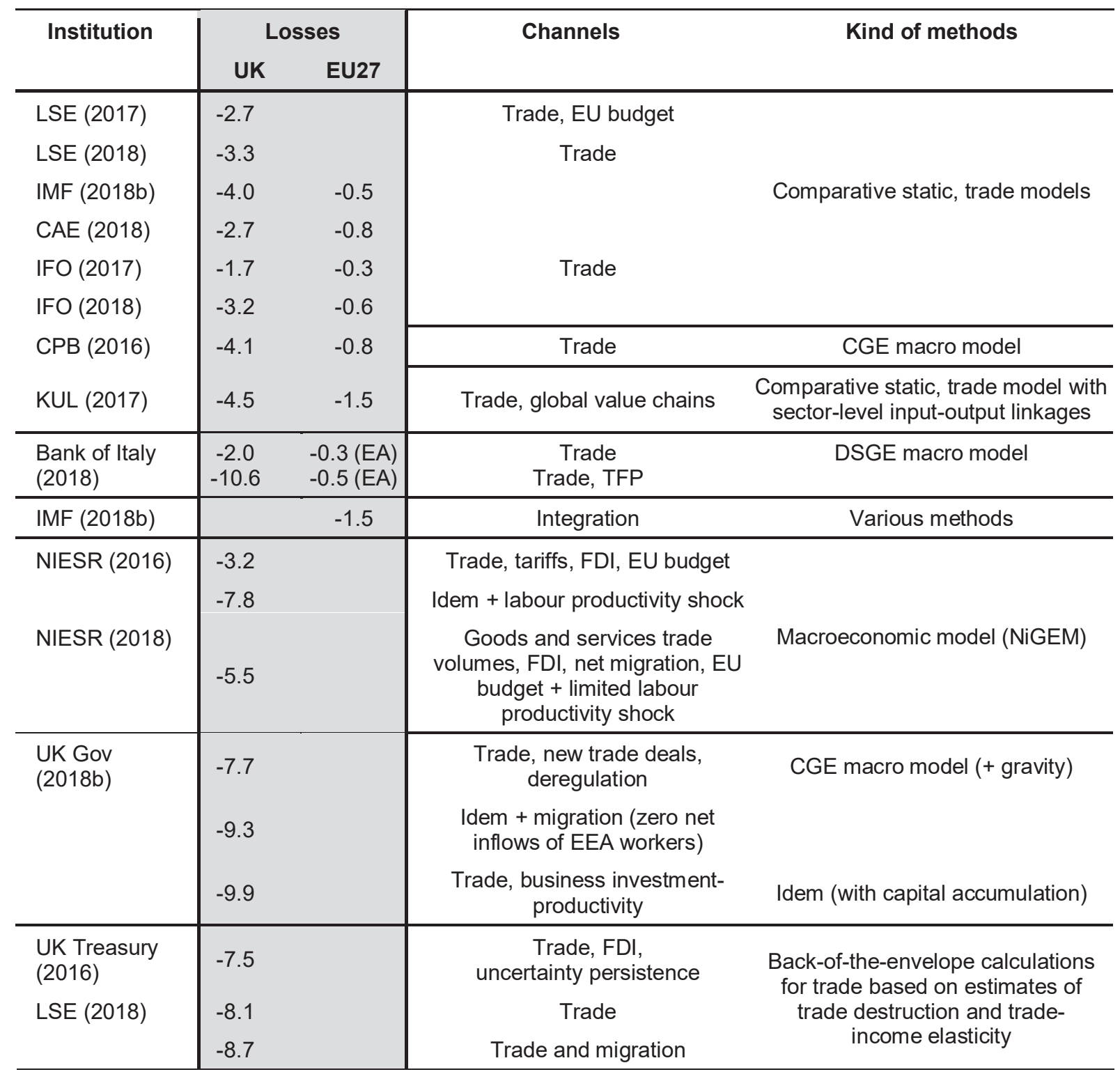

SOURCES: Dhingra et al. (2017), Ebell and Warren (2016), Felbermayr et al. (2017 and 2018), IMF (2018b), Pisani and Vergara Caffarelli (2018), Rojas-Romagosa (2016), UK Government (2018), UK Treasury (2016), Vandenbussche et al. (2017a), Vicard (2018). 


\subsection{A shock to the export equation of countries}

The export equation of each country $i$ to destination country j can be expressed from a CES structure as:

$$
X_{i j}=\left(p_{i}\left(1+\tau_{i j}\right)\right)^{-\sigma} Y_{j}\left(P_{j}\right)^{\sigma-1}
$$

In this expression $X_{i j}$ is the volume of exports from country i to country $j$, and $p_{i}\left(1+\tau_{i j}\right)$ is the price of the exported good at factory gate in country $I\left(p_{i}\right)$ times the import tariff $\left(\tau_{i j}\right)$ in country $\mathrm{j}$ applied to goods shipped from country $\mathrm{i}$. A key parameter is the elasticity of substitution which represents the substitutability of goods within an industry. In the context of the previous expression, this is also a trade elasticity that governs the response of export volumes to changes in prices and tariffs. This elasticity takes different values in the trade literature and in the calibration exercise we will use an elasticity of $\sigma=4$ estimated in Caliendo and Parro (2015) based on foreign-applied tariffs and French firm-level export data.

Taking logs and first differentiating, we obtain:

$$
\Delta \ln X_{\mathrm{ij}}=-\sigma \Delta \ln \left(\mathrm{p}_{\mathrm{i}}\right)-\sigma \Delta \ln \left(1+\tau_{\mathrm{ij}}\right)+\Delta \ln \mathrm{Y}_{\mathrm{j}}+(\sigma-1) \Delta \ln \mathrm{P}_{\mathrm{j}}
$$

All other things being equal, the variation of exports is driven by the change in foreign import tariffs with an elasticity $\sigma$. Note this is only the partial equilibrium effect of tariffs, as changes in foreign import tariffs can also modify the import price index (the price of competitors in macroeconomic models). As NiGEM already accounts for the GE effects, we will use the partial equilibrium response to calibrate shock in our simulation.

$$
\frac{\Delta \ln X_{i j}}{\Delta \ln \left(1+\tau_{i j}\right)}=-\sigma
$$

This is the elasticity of export volumes to changes in tariffs. The percentage variation of exports consecutive to a $1 \%$ change in tariffs is given by:

$$
\frac{\Delta \mathrm{X}_{\mathrm{ij}}}{\mathrm{X}_{\mathrm{ij}}}=\exp \left[-\sigma \Delta \ln \left(1+\tau_{\mathrm{ij}}\right)\right]-1
$$

To calibrate the shock on the export equation in NiGEM, we also need to account for the share of total exports covered by the trade measure. In our simulation, this is going to be highly asymmetric, as the EU represents a large share of British exports, whereas the United Kingdom represents a small share of each individual EU countries' exports.

The change in total exports for each individual country $\mathrm{i}$ is therefore calibrated as follows:

$$
\frac{\Delta \mathrm{X}_{\mathrm{i}}}{\mathrm{X}_{\mathrm{i}}}=\sum_{\mathrm{j}} \omega_{\mathrm{ij}} \frac{\Delta \mathrm{X}_{\mathrm{ij}}}{\mathrm{X}_{\mathrm{ij}}}=\sum_{\mathrm{j}} \omega_{\mathrm{ij}}\left(\exp \left[-\Delta \sigma \ln \left(1+\tau_{\mathrm{ij}}\right)\right]-1\right)
$$




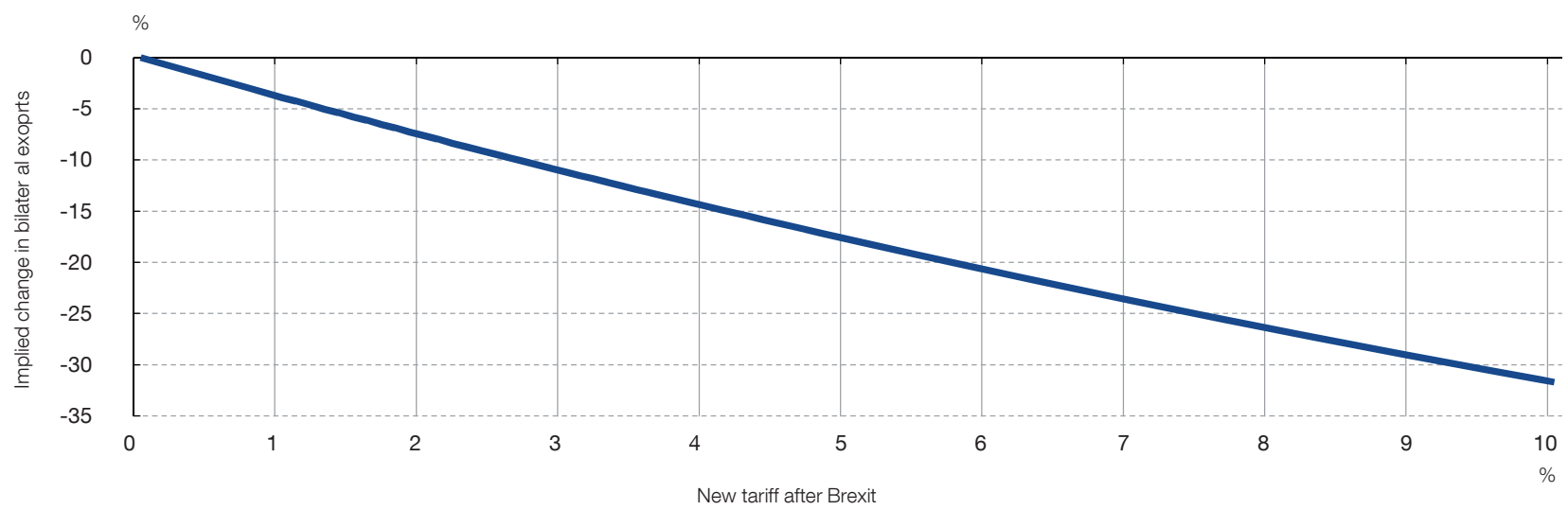

Where $\omega_{i j}=\frac{X_{i j}}{X}$ is the trade share of country $j$ in country i's exports as given by the trade matrix in NiGEM. We summarise in Table 1 the implied export shocks that we implement for the Brexit simulation and for each country.

\subsection{A shock to the import equation of countries}

Unlike trade models, NiGEM has separate equations for exports and imports, which implies that the shock on tariffs needs to be replicated in the export and in the import equations of the model. To calibrate the shock on the import side, we consider - as for the export equation a CES framework. The import volume $M$ of country $j$ from country $i, M_{i j}$, can be expressed as follows:

$$
M_{i j}=\left(p_{i}\left(1+\tau_{i j}\right)\right)^{-\sigma} Y_{j}\left(P_{j}\right)^{\sigma-1}
$$

This is the exact same equation as for the exports, but in Nigem aggregate exports and imports are two different objects and we need to shock them both.

Unlike with the export equation, we cannot shock directly here the import demand (total final expenditure, equal to domestic demand plus exports), as this is an endogenous variable that will respond to the shock in general equilibrium. We can, however, implement a shock on the import price corresponding to the increase in tariffs. Importantly, we do not have a tariff variable in Nigem, so the shock has to be on the c.i.f. import price variable $p_{i j}=p_{i}\left(1+\tau_{i j}\right)$.

The aggregation of this expression over all foreign trade partners gives us an expression for the total import volume of country j:

$$
\ln M_{i j}=-\sigma \ln \left[p_{i}\left(1+\tau_{i j}\right)\right]+\ln Y_{j}+(\sigma-1) \ln P_{j}
$$


The log of total imports by country j, InM, can be expressed as a weighted average of bilateral imports from each country, where $\theta_{i j}=\frac{M_{i j}}{M_{j}}$ represents the share of country $i$ in $j$ 's total imports;

$$
\ln M_{j}=\sum_{i} \theta_{i j} \ln M_{i j}=-\sigma \mid n P_{j}^{M}+\ln Y_{j}+(\sigma-1) \ln P_{j}
$$

Where $P_{j}^{M}=\sum_{i} \theta_{i j} \ln \left[p_{i}\left(1+\tau_{i j}\right)\right]$ is the import price index of country $j$, whereas is the price of goods sold domestically in j's market, including those produced at home.

This import equation, which is standard in trade models and relies on a trade elasticity, is very similar to the import volume equation in Nigem. However, the import price elasticity in Nigem (often around 1) is much lower than that commonly used in trade models for assessing the impact of tariffs (4 as above or more). This means that without changing the elasticity in Nigem, which is well calibrated for instance to assess the impact of real exchange rate movements, we need to calibrate the price shock in order to make it consistent with the response of import volumes in trade models.

$$
\begin{aligned}
& -\varepsilon^{\text {nigem }} \Delta \ln P_{j}^{M}=\sum_{i} \theta_{i j}\left(-\sigma \Delta \ln \left[p_{i}\left(1+\tau_{i j}\right)\right]\right) \\
& \Leftrightarrow \Delta \operatorname{lnP} P_{j}^{M}=\sum_{i} \theta_{i j}\left(\frac{\sigma}{\varepsilon^{\text {nigem }}} \Delta \ln \left[p_{i}\left(1+\tau_{i j}\right)\right]\right)
\end{aligned}
$$

The calibrated change in the import price can be obtained from the following formula:

$$
\frac{\Delta \mathrm{P}_{\mathrm{j}}^{\mathrm{M}}}{\mathrm{P}_{\mathrm{j}}^{\mathrm{M}}}=\exp \left(\Delta \ln \mathrm{P}_{\mathrm{j}}^{\mathrm{M}}\right)-1=\exp \left(\sum_{\mathrm{i}} \theta_{\mathrm{ij}}\left(\frac{\sigma}{\varepsilon^{\mathrm{nigem}}} \Delta \ln \left[\mathrm{p}_{\mathrm{i}}\left(1+\tau_{\mathrm{i}}\right)\right]\right)\right)-1
$$

The shocks on the import price, reported in Table 2, range from about $+13 \%$ in the United Kingdom, and about $+1 \%$ for the EU countries except Ireland. It is important to note here that this does not correspond per se to the import price increase that we expect to observe in the case of a Brexit with a WTO scenario, but the price shock that is required to calibrate the increase in tariffs with the appropriate price elasticity of demand. 


\title{
BANCO DE ESPAÑA PUBLICATIONS
}

\author{
OCCASIONAL PAPERS
}

1401 JOSÉ MARÍA SERENA and EVA VALDEOLIVAS: Integración financiera y modelos de financiación de los bancos globales.

1402 ANTONIO MONTESINOS, JAVIER J. PÉREZ and ROBERTO RAMOS: El empleo de las Administraciones Públicas en España: caracterización y evolución durante la crisis.

1403 SAMUEL HURTADO, PABLO MANZANO, EVA ORTEGA and ALBERTO URTASUN: Update and re-estimation of the Quarterly Model of Banco de España (MTBE).

1404 JUAN CARLOS BERGANZA, IGNACIO HERNANDO and JAVIER VALLÉS: Los desafíos para la política monetaria en las economías avanzadas tras la Gran Recesión.

1405 FERNANDO LÓPEZ VICENTE and JOSÉ MARÍA SERENA GARRALDA: Macroeconomic policy in Brazil: inflation targeting, public debt structure and credit policies.

1406 PABLO HERNÁNDEZ DE COS and DAVID LÓPEZ RODRÍGUEZ: Tax structure and revenue-raising capacity in Spain: A comparative analysis with the UE. (There is a Spanish version of this edition with the same number).

1407 OLYMPIA BOVER, ENRIQUE CORONADO and PILAR VELILLA: The Spanish survey of household finances (EFF): description and methods of the 2011 wave.

1501 MAR DELGADO TÉLLEZ, PABLO HERNÁNDEZ DE COS, SAMUEL HURTADO and JAVIER J. PÉREZ: Extraordinary mechanisms for payment of General Government suppliers in Spain. (There is a Spanish version of this edition with the same number).

1502 JOSÉ MANUEL MONTERO y ANA REGIL: La tasa de actividad en España: resistencia cíclica, determinantes y perspectivas futuras.

1503 MARIO IZQUIERDO and JUAN FRANCISCO JIMENO: Employment, wage and price reactions to the crisis in Spain: Firm-level evidence from the WDN survey.

1504 MARÍA DE LOS LLANOS MATEA: La demanda potencial de vivienda principal.

1601 JESÚS SAURINA and FRANCISCO JAVIER MENCÍA: Macroprudential policy: objectives, instruments and indicators. (There is a Spanish version of this edition with the same number).

1602 LUIS MOLINA, ESTHER LÓPEZ y ENRIQUE ALBEROLA: El posicionamiento exterior de la economía española.

1603 PILAR CUADRADO and ENRIQUE MORAL-BENITO: Potential growth of the Spanish economy. (There is a Spanish version of this edition with the same number).

1604 HENRIQUE S. BASSO and JAMES COSTAIN: Macroprudential theory: advances and challenges.

1605 PABLO HERNÁNDEZ DE COS, AITOR LACUESTA and ENRIQUE MORAL-BENITO: An exploration of real-time revisions of output gap estimates across European countries.

1606 PABLO HERNÁNDEZ DE COS, SAMUEL HURTADO, FRANCISCO MARTÍ and JAVIER J. PÉREZ: Public finances and inflation: the case of Spain.

1607 JAVIER J. PÉREZ, MARIE AOURIRI, MARÍA M. CAMPOS, DMITRIJ CELOV, DOMENICO DEPALO, EVANGELIA PAPAPETROU, JURGA PESLIAKAITÉ, ROBERTO RAMOS and MARTA RODRÍGUEZ-VIVES: The fiscal and macroeconomic effects of government wages and employment reform.

1608 JUAN CARLOS BERGANZA, PEDRO DEL RÍO and FRUCTUOSO BORRALLO: Determinants and implications of low global inflation rates.

1701 PABLO HERNÁNDEZ DE COS, JUAN FRANCISCO JIMENO and ROBERTO RAMOS: The Spanish public pension system: current situation, challenges and reform alternatives. (There is a Spanish version of this edition with the same number).

1702 EDUARDO BANDRÉS, MARÍA DOLORES GADEA-RIVAS and ANA GÓMEZ-LOSCOS: Regional business cycles across Europe.

1703 LUIS J. ÁLVAREZ and ISABEL SÁNCHEZ: A suite of inflation forecasting models.

1704 MARIO IZQUIERDO, JUAN FRANCISCO JIMENO, THEODORA KOSMA, ANA LAMO, STEPHEN MILLARD, TAIRI RÕÕM and ELIANA VIVIANO: Labour market adjustment in Europe during the crisis: microeconomic evidence from the Wage Dynamics Network survey.

1705 ÁNGEL LUIS GÓMEZ and M. ${ }^{a}$ DEL CARMEN SÁNCHEZ: Indicadores para el seguimiento y previsión de la inversión en construcción.

1706 DANILO LEIVA-LEON: Monitoring the Spanish Economy through the Lenses of Structural Bayesian VARs.

1707 OLYMPIA BOVER, JOSÉ MARÍA CASADO, ESTEBAN GARCÍA-MIRALLES, JOSÉ MARÍA LABEAGA and ROBERTO RAMOS: Microsimulation tools for the evaluation of fiscal policy reforms at the Banco de España.

1708 VICENTE SALAS, LUCIO SAN JUAN and JAVIER VALLÉS: The financial and real performance of non-financial corporations in the euro area: 1999-2015. 
1709 ANA ARENCIBIA PAREJA, SAMUEL HURTADO, MERCEDES DE LUIS LÓPEZ and EVA ORTEGA: New version of the Quarterly Model of Banco de España (MTBE).

1801 ANA ARENCIBIA PAREJA, ANA GÓMEZ LOSCOS, MERCEDES DE LUIS LÓPEZ and GABRIEL PÉREZ QUIRÓS: A short-term forecasting model for the Spanish economy: GDP and its demand components.

1802 MIGUEL ALMUNIA, DAVID LÓPEZ-RODRÍGUEZ and ENRIQUE MORAL-BENITO: Evaluating the macro-representativeness of a firm-level database: an application for the Spanish economy.

1803 PABLO HERNÁNDEZ DE COS, DAVID LÓPEZ RODRíGUEZ and JAVIER J. PÉREZ: The challenges of public deleveraging. (There is a Spanish version of this edition with the same number).

1804 OLYMPIA BOVER, LAURA CRESPO, CARLOS GENTO and ISMAEL MORENO: The Spanish Survey of Household Finances (EFF): description and methods of the 2014 wave.

1805 ENRIQUE MORAL-BENITO: The microeconomic origins of the Spanish boom.

1806 BRINDUSA ANGHEL, HENRIQUE BASSO, OLYMPIA BOVER, JOSÉ MARÍA CASADO, LAURA HOSPIDO, MARIO IZQUIERDO, IVAN A. KATARYNIUK, AITOR LACUESTA, JOSÉ MANUEL MONTERO and ELENA VOZMEDIANO: Income, consumption and wealth inequality in Spain. (There is a Spanish version of this edition with the same number).

1807 MAR DELGADO-TÉLLEZ and JAVIER J. PÉREZ: Institutional and economic determinants of regional public debt in Spain.

1808 CHENXU FU and ENRIQUE MORAL-BENITO: The evolution of Spanish total factor productivity since the Global Financial Crisis.

1809 CONCHA ARTOLA, ALEJANDRO FIORITO, MARÍA GIL, JAVIER J. PÉREZ, ALBERTO URTASUN and DIEGO VILA: Monitoring the Spanish economy from a regional perspective: main elements of analysis.

1810 DAVID LÓPEZ-RODRÍGUEZ and CRISTINA GARCÍA CIRIA: Estructura impositiva de España en el contexto de la Unión Europea.

1811 JORGE MARTÍNEZ: Previsión de la carga de intereses de las Administraciones Públicas.

1901 CARLOS CONESA: Bitcoin: a solution for payment systems or a solution in search of a problem? (There is a Spanish version of this edition with the same number).

1902 AITOR LACUESTA, MARIO IZQUIERDO and SERGIO PUENTE: An analysis of the impact of the rise in the national minimum wage in 2017 on the probability of job loss. (There is a Spanish version of this edition with the same number).

1903 EDUARDO GUTIÉRREZ CHACÓN and CÉSAR MARTíN MACHUCA: Exporting Spanish firms. Stylized facts and trends.

1904 MARÍA GIL, DANILO LEIVA-LEON, JAVIER J. PÉREZ and ALBERTO URTASUN: An application of dynamic factor models to nowcast regional economic activity in Spain.

1905 JUAN LUIS VEGA (COORD.): Brexit: current situation and outlook.

1906 JORGE E. GALÁN: Measuring credit-to-GDP gaps. The Hodrick-Prescott filter revisited.

1907 VÍCTOR GONZÁLEZ-DÍEZ and ENRIQUE MORAL-BENITO: The process of structural change in the Spanish economy from a historical standpoint. (There is a Spanish version of this edition with the same number).

1908 PANA ALVES, DANIEL DEJUÁN and LAURENT MAURIN: Can survey-based information help assess investment gaps in the EU?

1909 OLYMPIA BOVER, LAURA HOSPIDO and ERNESTO VILLANUEVA: The Survey of Financial Competences (ECF): description and methods of the 2016 wave.

1910 LUIS JULIÁN ÁLVAREZ: El índice de precios de consumo: usos y posibles vías de mejora.

1911 ANTOINE BERTHOU, ÁNGEL ESTRADA, SOPHIE HAINCOURT, ALEXANDER KADOW, MORITZ A. ROTH and MARIE-ELISABETH DE LA SERVE: Assessing the macroeconomic impact of Brexit through trade and migration channels.

\section{BANCODEESPAÑA}

Eurosistema
Unidad de Servicios Auxiliares

Alcalá, 48 - 28014 Madrid

E-mail: publicaciones@bde.es www.bde.es 